\title{
Synthesis, Characterization, Spectral Studies, Antibacterial Evaluation, Thermodynamics and DFT Calculations of Dimethyltin(IV) Dichloride Schiff Base
}

\author{
Sheida Esmaielzadeh, ${ }^{1, *}$ Khadijeh Shekoohi, ${ }^{1}$ Mohammad Sharif-Mohammadi, ${ }^{2}$ \\ Ghazal Mashhadiagha ${ }^{3}$ and Khosro Mohammadi ${ }^{4}$ \\ ${ }^{1}$ Department of Chemistry, Darab branch, Islamic Azad University, Darab 7481783143-196, I. R. Iran \\ ${ }^{2}$ Department of Chemistry, Firozabad branch, Islamic Azad University, Firozabad 74715-117, I. R. Iran \\ ${ }^{3}$ Chemistry Department, College of Sciences, Shiraz University, Shiraz, 71454, I. R. Iran \\ ${ }^{4}$ Chemistry Department, Faculty of Sciences, Persian Gulf University, Bushehr 75169, I. R. Iran \\ * Corresponding author: E-mail: esmaielzadehsheida@yahoo.com
}

Received: 16-03-2015

\begin{abstract}
A number of new 1:1 complexes of $\mathrm{SnMe}_{2} \mathrm{Cl}_{2}$ with unsymmetrical tetradentate Schiff base ligand with NNOS coordination sphere have been synthesized and fully characterized by a variety of physico-chemical techniques viz. elemental analysis, molar conductivity, ${ }^{1} \mathrm{H}$ and ${ }^{119} \mathrm{Sn}$ NMR, IR and mass spectroscopy. IR spectral data show that the fifth coordination position of tin atom is occupied by an oxygen atom of Schiff base ligands. In the light of titled techniques, trigonal bipyramidal geometry around the tin atom is proposed for the synthesized complexes. The in vitro antibacterial activities of the complexes against Staphylococcus aureus and Escherichia Coli have been studied. It was found that they possess significant antibacterial activity. Also, DFT/B3LYP method was used to analyze the electronic structures and study of the geometries. The thermodynamic formation constants of the complexes were determined spectrophotometrically at $25^{\circ} \mathrm{C}$ in DMF solvent.
\end{abstract}

Keywords: Tin(IV) complex; Schiff base; DFT method; Antibacterial activity; Formation constants

\section{Introduction}

Schiff bases have played a special role as chelating ligands in main group and transition metal coordination chemistry because of their stability under a variety of redox conditions and because imine ligands are borderline Lewis bases. Schiff bases as versatile organic blockers have recently attracted great attention due to their preparative accessibilities, molecular architectures and varied denticities. ${ }^{1,2}$ This compounds with strong donor atom are excellent in catalysis and biological replication due to their strong coordination abilities with metal ions. ${ }^{3}$

There are several reports on metal complexes such as $\mathrm{Ni}(\mathrm{II}), \mathrm{Cu}(\mathrm{II}), \mathrm{Co}(\mathrm{II})$ and $\mathrm{Sn}(\mathrm{IV})$ of the Schiff base ligands that have a variety of applications including bioche- mical reactions and biological regulators, ${ }^{4,5}$ clinical, ${ }^{6,7}$ analytical $^{8,9}$ and industrial uses in addition to their important roles in enhancing the solubility and stability of homogeneous or heterogeneous catalysts. ${ }^{10-12}$

Over the years, much effort has done on coordination of Schiff bases to organotin(IV) compounds. An enormous number of organotin compounds are used as pharmaceuticals, pesticides, stabilizers, fire retardants, miticides, molluscicides, marine antifouling paints, surface disinfectants, wood preservatives, in medicinal chemistry and biotechnology and due to their structural variety. ${ }^{14-16}$ Organotins with three organic groups can be powerful fungicides and bactericides, depending on the organic group. ${ }^{17-20}$

Tin has a large number of organometallic derivatives that are used commercially. Nowadays, efforts have been 
devoted to design and synthesis of organotin(IV) compounds with flexible Schiff base ligands that can adopt various coordination modes. The main objective is to produce new functional materials with specific molecular arrangements capable of showing the desirable properties with NNOS flexible donor Schiff base ligands. The competition between chelating and bridging coordination mode is an important factor in producing mono, di and polynuclear metal complexes. ${ }^{2-23}$

In view of the importance of tin compounds in medicinal chemistry and as a part of our ongoing work on metal Schiff base complexes, ${ }^{24-27}$ herein, we describe synthesis and characterization of some tin(IV) Schiff base complexes with general formula $\left[\mathrm{SnMe}_{2} \mathrm{Cl}_{2}\left(\mathrm{H}_{2} \mathrm{~L}\right)\right]$ (where $\mathrm{L}=$ cdac $\mathrm{CF}_{3}$ en = methyl-2- $\{N$-[2-(acetone)triflourolidynenitrilo]ethyl $\}$ amino-1-cyclopentenedithiocarboxylate, cdacacen $=$ methyl $-2-\{N-[2-($ acetone $)$ ethylidynenitrilo $]$ ethyl $\}$ amino-1-cyclopentenedithiocarbox-ylate, cdacPhen = methyl-2-\{N-[2-(acetone)phenylidynenitrilo]ethyl $\}$ amino-1-cyclopentene-dithiocarboxylate, cdacacMeen = methyl-2-\{[1-methyl-2-(acetone)ethylidynenitrilo] ethyl $\}$ amino-1-cyclopentenedithiocarboxylate, cdacacpd = methyl-2-\{[1-methyl-2-(acetone)ethylidynenitrilo]-propyl $\}$ amino-1-cyclopentenedithiocarboxylate). This work is also extended to present some well- known properties of the complexes, such as plausible descriptions of stability constants, HOMO-LUMO orbital energies and dipole moments as ascribed on the basis of DFT calculations. In addition to the importance of the experimental studies, the formation constants were determined spectrophotometrically. The effects of the electronic and steric nature of substituents on the Schiff base type ligands on the formation constants resulting from complex formation were studied. The in vitro antibacterial behavior of the ligand and their tin(IV) complexes was studied by disk diffusion method.

\section{Experimental}

\section{1. Material and Methods}

All the chemicals and solvents were of analytical reagent grade quality. Benzoylacetone, acetylacetone, 1,1,1-trifluoro-2,4-pentanedione, 1,2-ethylenediamine, 1,2-diaminopropane, 1,3-diaminopropane, ammonia solution, carbon disulfide, dimethylsulfate, cyclopentanone, methanol, ethanol, chloroform, dimethylformamide, hydrochloric acid and dimethyltindichloride were purchased from Merck, Fluka and Aldrich chemical companies and were used as received without further purification.

The melting points of the compounds were determined by a melting point apparatus SMP1 stuart scientific. The IR spectra were recorded by Shimadzu FTIR 8300 infrared spectrophotometer in the range of $400-4000 \mathrm{~cm}^{-1}$ as $\mathrm{KBr}$ discs. Mass spectra were obtained on Perkin Elmer R MU-6E instrument. Elemental analyses (CHNS) were performed on a Termo Fininngan-Flash-1200 elemental analyzer. The molar conductance of ca. $10^{-3} \mathrm{M}$ solutions at $25 \pm 1{ }^{\circ} \mathrm{C}$ of the complexes in DMF were measured by means of a Jenway 4310 conductivity meter and a diptype cell with a platinized electrode. ${ }^{1} \mathrm{H}$ NMR spectra were acquired on Bruker Avance DPX $250 \mathrm{MHz}$ instruments. ${ }^{119} \mathrm{Sn}$ NMR spectra were recorded on Bruker Avance DPX $400 \mathrm{MHz}$ spectrometer using $\mathrm{SnMe}_{4}$ as references.

\section{2. Preparation of the Schiff Base Ligands}

To a solution of half unites ligands methyl-2-\{N( $2^{\times}$-aminoethane $\left.)\right\}$-amino-1-cyclopentenedithiocarboxylate (Hcden), ${ }^{28,29}$ methyl-2-(1-methyl-2'-aminoethane) amino-1-cyclopentenedithiocarboxylate (HcdMeen $)^{24,25}$ and methyl-2-(3-aminopropyl)amino-1-cyclopentenedithiocarboxylate $(\mathrm{Hcdpd})^{27}(1 \mathrm{mmol})$ in methanol $(20 \mathrm{~mL})$ was added, with continuous stirring, diketon's derivatives (1mmol).

The mixture was stirred for about $30 \mathrm{~min}$ to give a yellow precipitate. The products were filtered and washed with methanol/chloroform 1:1 (V:V). The structures are given in Scheme 1.

\section{3. Preparation of the Tin(IV) Schiff Base Complexes}

Schiff base ligands ( $1 \mathrm{mmol}, 0.21 \mathrm{~g}$ Hcden and $0.23 \mathrm{~g}$ HcdMeen, Hcdpd) were dissolved in $20 \mathrm{~mL}$ of benzene and added to $20 \mathrm{~mL}$ benzene solution of $\mathrm{SnMe}_{2} \mathrm{Cl}_{2}(2 \mathrm{mmol}$, $0.44 \mathrm{~g}$ ). The resulting mixture obtained was stirred for $24 \mathrm{~h}$. After allowing it to stand in air at room temperature, the yellow precipitated complexes were filtered off, washed with benzene and then dried over anhydrous $\mathrm{CaCl}_{2}$.

\section{3. 1. $\left[\mathrm{SnMe}_{2} \mathrm{Cl}_{2}\left(\mathrm{H}_{2} \mathrm{CdacCF}_{3}\right.\right.$ en)]: \{methyl-2-[N- [2-(acetonate)triflourolidynenitrilo]ethyl\}- aminato(-1)-1-cyclopentenedithiocarboxy- late dimethyltindichloride}

Yield: $67 \%$; m.p.: $127{ }^{\circ} \mathrm{C} ;{ }^{1} \mathrm{H}$ NMR $(\delta$, ppm, 250 MHz, DMSO- $d_{6}$ ): 1.27 (s, $\left.6 \mathrm{H}, \mathrm{Sn}-\mathrm{Me}\right), 1.89\left(\mathrm{~m}, 2 \mathrm{H}, \mathrm{H}^{4}\right)$, $2.30\left(\mathrm{~s}, 3 \mathrm{H}, \mathrm{CH}_{3}\right), 2.57\left(\mathrm{~s}, 3 \mathrm{H}, \mathrm{SCH}_{3}\right), 2.70-2.91(\mathrm{~m}, 4 \mathrm{H}$, $\left.\mathrm{H}^{3,}, 5^{\prime}\right), 3.51-3.74\left(\mathrm{~m}, 4 \mathrm{H}, \mathrm{H}^{\mathrm{en}}\right), 5.61\left(\mathrm{~s}, 1 \mathrm{H}, \mathrm{H}^{\mathrm{a}}\right), 11.64(\mathrm{br}$, $1 \mathrm{H}, \mathrm{NH}), 12.43(\mathrm{br}, 1 \mathrm{H}, \mathrm{OH}) ;{ }^{119} \mathrm{Sn}$ NMR $(\delta, \mathrm{ppm}, 400$ MHz, DMSO- $\left.d_{6}\right)$ : -121.73 ; FT-IR $\left(\mathrm{KBr}, \mathrm{cm}^{-1}\right): 3170$ $\left(\mathrm{v}_{\mathrm{NH}}\right) ; 2960\left(\mathrm{v}_{\mathrm{CH}}\right) ; 1640\left(\mathrm{v}_{\mathrm{C}=\mathrm{N}}\right) ; 1490\left(\mathrm{v}_{\mathrm{C}=\mathrm{C}}\right) ; 1238\left(\mathrm{v}_{\mathrm{CO}}\right)$; $1100\left(v_{\mathrm{CN}+\mathrm{CS}}\right) ; 720\left(v_{\mathrm{CS}}\right) ; 480\left(\mathrm{v}_{\mathrm{SnO}}\right)$.

\section{3. 2. $\left[\mathrm{SnMe}_{2} \mathrm{Cl}_{2}\left(\mathrm{H}_{2}\right.\right.$ cdacacen $\left.)\right]:\{$ methyl-2- $[\mathrm{N}-$ [2-(acetonate)ethylidynenitrilo]ethyl \}ami- nato(-1)-1-cyclopentenedithiocarboxylate dimethyltindichloride.}

Yield: $61 \%$; m.p.: $120{ }^{\circ} \mathrm{C} ;{ }^{1} \mathrm{H}$ NMR $(\delta$, ppm, 250 MHz, DMSO- $d_{6}$ ): 1.23 (s, 6H, Sn-Me), 1.87 (m, 2H, $\mathrm{H}^{4}$ ), 
$1.93\left(\mathrm{~s}, 3 \mathrm{H}, \mathrm{CH}_{3}\right), 2.03\left(\mathrm{~s}, 3 \mathrm{H}, \mathrm{CH}_{3}\right), 2.58\left(\mathrm{~s}, 3 \mathrm{H}, \mathrm{SCH}_{3}\right)$, $2.71\left(\mathrm{t}, 2 \mathrm{H}, \mathrm{H}^{5}\right), 2.81\left(\mathrm{t}, 2 \mathrm{H}, \mathrm{H}^{3}\right), 3.51-3.63\left(\mathrm{~m}, 4 \mathrm{H}, \mathrm{H}^{\mathrm{en}}\right)$, $5.03\left(\mathrm{~s}, 1 \mathrm{H}, \mathrm{H}^{\mathrm{a}}\right), 11.03(\mathrm{br}, 1 \mathrm{H}, \mathrm{NH}), 12.43(\mathrm{br}, 1 \mathrm{H}, \mathrm{OH})$; ${ }^{119} \mathrm{Sn}$ NMR $\left(\delta\right.$, ppm, $400 \mathrm{MHz}$, DMSO- $\left.d_{6}\right):-120.12$; FTIR $\left(\mathrm{KBr}, \mathrm{cm}^{-1}\right): 3091\left(\mathrm{v}_{\mathrm{NH}}\right) ; 2950\left(\mathrm{v}_{\mathrm{CH}}\right) ; 1604\left(\mathrm{v}_{\mathrm{C}=\mathrm{N}}\right) ; 1438$ $\left(v_{\mathrm{C}=\mathrm{C}}\right) ; 1275\left(\mathrm{v}_{\mathrm{CO}}\right) ; 1010\left(\mathrm{v}_{\mathrm{CN}+\mathrm{CS}}\right) ; 759\left(\mathrm{v}_{\mathrm{CS}}\right) ; 423\left(\mathrm{v}_{\mathrm{SnO}}\right)$.

\section{3. 3 [SnMe $\mathrm{Sl}_{2}\left(\mathrm{H}_{2}\right.$ cdacPhen $\left.)\right]:$ \{methyl-2-[N- [2-(acetonate)phenylidynenitrilo]ethyl \}ami- nato(-1)-1-cyclopentenedithiocarboxylate dimethyltindichloride.}

Yield: $67 \%$; m.p.: $122{ }^{\circ} \mathrm{C} ;{ }^{1} \mathrm{H}$ NMR $(\delta$, ppm, 250 MHz, DMSO- $d_{6}$ ): 1.25 (s, 6H, Sn-Me), $1.86\left(\mathrm{~m}, 2 \mathrm{H}, \mathrm{H}^{4}\right.$ ), $2.12\left(\mathrm{~s}, 3 \mathrm{H}, \mathrm{CH}_{3}\right), 2.58\left(\mathrm{~s}, 3 \mathrm{H}, \mathrm{SCH}_{3}\right), 2.70-2.88(\mathrm{~m}, 4 \mathrm{H}$, $\left.\mathrm{H}^{3}, 5^{\prime}\right), 3.49-3.68\left(\mathrm{~m}, 4 \mathrm{H}, \mathrm{H}^{\mathrm{en}}\right), 5.71\left(\mathrm{~s}, 1 \mathrm{H}, \mathrm{H}^{\mathrm{a}}\right), 7.41(1 \mathrm{H}$, $\left.\mathrm{m}, \mathrm{H}^{1 \ll \mathrm{Ph}}\right), 7.81-7.88\left(4 \mathrm{H}, \mathrm{d}, \mathrm{H}^{2 \ll, 3 \ll \mathrm{Ph}}\right) ; 11.60(\mathrm{br}, 1 \mathrm{H}, \mathrm{NH})$, 12.52 (br, $1 \mathrm{H}, \mathrm{OH}) ;{ }^{119} \mathrm{Sn}$ NMR $(\delta$, ppm, $400 \mathrm{MHz}, \mathrm{DM}-$ SO- $\left.d_{6}\right):-123.40$; FT-IR $\left(\mathrm{KBr}, \mathrm{cm}^{-1}\right): 3105\left(\mathrm{v}_{\mathrm{NH}}\right) ; 2930$ $\left(v_{\mathrm{CH}}\right) ; 1600\left(v_{\mathrm{C}=\mathrm{N}}\right) ; 1470\left(v_{\mathrm{C}=\mathrm{C}}\right) ; 1240\left(\mathrm{v}_{\mathrm{CO}}\right) ; 1119$ $\left(v_{\mathrm{CN}+\mathrm{CS}}\right) ; 750\left(v_{\mathrm{CS}}\right) ; 463\left(v_{\mathrm{SnO}}\right)$.

\section{3. 4. $\left[\mathrm{SnMe}_{2} \mathrm{Cl}_{2}\left(\mathrm{H}_{2}\right.\right.$ cdacacMeen $\left.)\right]$ : \{methyl-2- \{[1-methyl-2-(acetonate) ethylidynenitri- lo]ethyl\}-aminato(-1)-1-cyclopentenedit- hiocarboxylate dimethyltindichloride.}

Yield: $58 \%$; m.p.: $112{ }^{\circ} \mathrm{C} ;{ }^{1} \mathrm{H}$ NMR $(\delta$, ppm, 250 MHz, DMSO- $d_{6}$ ): 1.22 (s, 6H, Sn-Me), 1.33 (s, 3H, Me), $1.85\left(\mathrm{~m}, 2 \mathrm{H}, \mathrm{H}^{4}\right), 1.95\left(\mathrm{~s}, 3 \mathrm{H}, \mathrm{CH}_{3}\right), 2.03\left(\mathrm{~s}, 3 \mathrm{H}, \mathrm{CH}_{3}\right)$, $2.58\left(\mathrm{~s}, 3 \mathrm{H}, \mathrm{SCH}_{3}\right), 2.68\left(\mathrm{t}, 2 \mathrm{H}, \mathrm{H}^{5^{\prime}}\right), 2.80\left(\mathrm{t}, 2 \mathrm{H}, \mathrm{H}^{33^{\prime}}\right)$, 3.40-3.81 (m, 3H, $\left.\mathrm{H}^{\mathrm{en}}\right), 5.01\left(\mathrm{~s}, 1 \mathrm{H}, \mathrm{H}^{\mathrm{a}}\right), 11.12(\mathrm{br}, 1 \mathrm{H}$, $\mathrm{NH}), 12.52$ (br, $1 \mathrm{H}, \mathrm{OH}) ;{ }^{119} \mathrm{Sn}$ NMR $(\delta, \mathrm{ppm}, 400 \mathrm{MHz}$, DMSO- $\left.d_{6}\right)$ : -127.61 ; FT-IR $\left(\mathrm{KBr}, \mathrm{cm}^{-1}\right): 3120\left(\mathrm{v}_{\mathrm{NH}}\right)$; $2900\left(v_{\mathrm{CH}}\right) ; 1608\left(v_{\mathrm{C}=\mathrm{N}}\right) ; 1408\left(v_{\mathrm{C}=\mathrm{C}}\right) ; 1261\left(\mathrm{v}_{\mathrm{CO}}\right) ; 1130$ $\left(v_{\mathrm{CN}+\mathrm{CS}}\right) ; 778\left(\mathrm{v}_{\mathrm{CS}}\right) ; 435\left(\mathrm{v}_{\mathrm{SnO}}\right)$.

\section{3. 5. $\left[\mathrm{SnMe}_{2} \mathrm{Clv}\left(\mathrm{H}_{2}\right.\right.$ cdacacpd $\left.)\right]:\{$ methyl-2- $\{[3-$ (acetonate)ethylidynenitrilo]propyl\}amina- to(-1)-1-cyclopentenedithiocarboxylate di- methyltindichloride.}

Yield: $67 \%$; m.p.: $120{ }^{\circ} \mathrm{C} ;{ }^{1} \mathrm{H}$ NMR $(\delta$, ppm, 250 MHz, DMSO- $\left.d_{6}\right): 1.25$ (s, 6H, Sn-Me), $1.88\left(\mathrm{~m}, 2 \mathrm{H}, \mathrm{H}^{4}\right)$, $1.92\left(\mathrm{~m}, 2 \mathrm{H}, \mathrm{H}^{2}\right), 1.98\left(\mathrm{~s}, 3 \mathrm{H}, \mathrm{CH}_{3}\right), 2.05\left(\mathrm{~s}, 3 \mathrm{H}, \mathrm{CH}_{3}\right)$, $2.58\left(\mathrm{~s}, 3 \mathrm{H}, \mathrm{SCH}_{3}\right), 2.71\left(\mathrm{t}, 2 \mathrm{H}, \mathrm{H}^{3}\right), 2.83\left(\mathrm{t}, 2 \mathrm{H}, \mathrm{H}^{5^{\prime}}\right)$, $3.47\left(\mathrm{t}, 2 \mathrm{H}, \mathrm{H}^{1 \ll}\right), 3.53\left(\mathrm{t}, 2 \mathrm{H}, \mathrm{H}^{3 \ll}\right), 5.70\left(\mathrm{~s}, 1 \mathrm{H}, \mathrm{H}^{\mathrm{a}}\right), 10.98$ (br, 1H, NH), 12.45 (br, $1 \mathrm{H}, \mathrm{OH}) ;{ }^{119} \mathrm{Sn}$ NMR $(\delta, \mathrm{ppm}$, $400 \mathrm{MHz}$, DMSO- $\left.d_{6}\right)$ : 125.34 ; FT-IR $\left(\mathrm{KBr}, \mathrm{cm}^{-1}\right): 3098$ $\left(v_{\mathrm{NH}}\right) ; 2958\left(\mathrm{v}_{\mathrm{CH}}\right) ; 1606\left(\mathrm{v}_{\mathrm{C}=\mathrm{N}}\right) ; 1468\left(\mathrm{v}_{\mathrm{C}=\mathrm{C}}\right) ; 1258\left(\mathrm{v}_{\mathrm{CO}}\right)$; $1112\left(v_{\mathrm{CN}+\mathrm{CS}}\right) ; 732\left(v_{\mathrm{CS}}\right) ; 453\left(\mathrm{v}_{\mathrm{SnO}}\right)$.

\section{4. In vitro Antibacterial Assay}

The synthesized tin(IV) Schiff base complexes were screened in vitro for their antibacterial properties by using
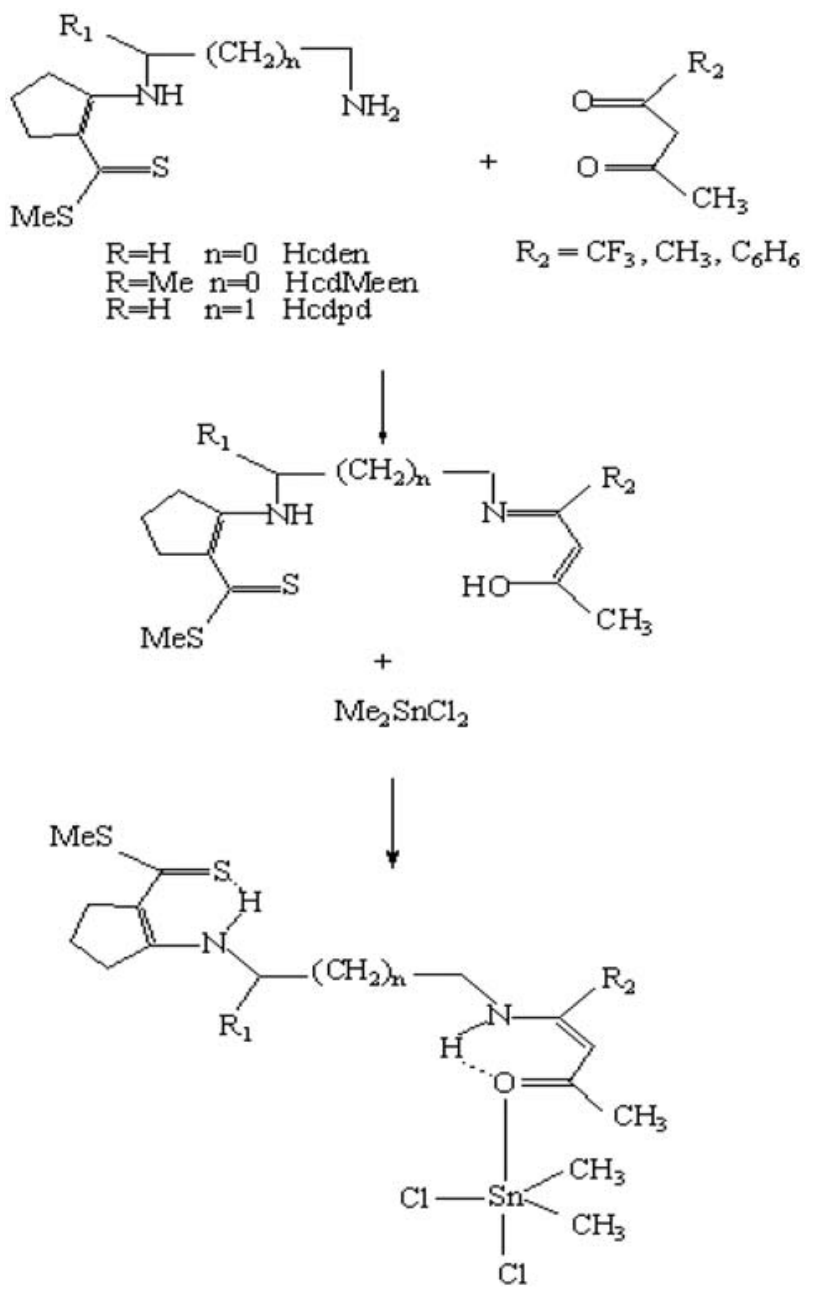

\begin{tabular}{lcccl}
\hline No & $\mathbf{R}_{\mathbf{1}}$ & $\mathbf{R}_{\mathbf{2}}$ & $\mathbf{n}$ & Abbreviation \\
\hline 1 & $\mathrm{H}$ & $\mathrm{CF}_{3}$ & 0 & {$\left[\mathrm{Me}_{2} \mathrm{SnCl}_{2} \mathrm{H}_{2}\right.$ cdacCF $\mathrm{CH}_{3}$ en $]$} \\
2 & $\mathrm{H}$ & $\mathrm{CH}_{3}$ & 0 & $\left[\mathrm{Me}_{2} \mathrm{SnCl}_{2} \mathrm{H}_{2}\right.$ cdacacen $\left.)\right]$ \\
3 & $\mathrm{H}$ & $\mathrm{C}_{6} \mathrm{H}_{6}$ & 0 & $\left[\mathrm{Me}_{2} \mathrm{SnCl}_{2} \mathrm{H}_{2}\right.$ cdacPhen $\left.)\right]$ \\
4 & $\mathrm{Me}$ & $\mathrm{CH}_{3}$ & 0 & $\left[\mathrm{Me}_{2} \mathrm{SnCl}_{2} \mathrm{H}_{2}\right.$ cdacacMeen $\left.)\right]$ \\
5 & $\mathrm{H}$ & $\mathrm{CH}_{3}$ & 1 & $\left[\mathrm{Me}_{2} \mathrm{SnCl}_{2} \mathrm{H}_{2}\right.$ cdacacpd $\left.)\right]$ \\
\hline
\end{tabular}

Scheme 1. The scheme for the synthesis of tin(IV) Schiff base complexes

Escherichia Coli and Staphylococcus aureous by using disk diffusion method. ${ }^{30}$ The tetracycline was used as a standard reference. The activity was determined by measuring the diameter of the inhibition zones (in $\mathrm{mm}$ ) showing complete inhibition.

\section{5. DFT Calculations}

The gas phase geometry of the tin(IV) Schiff base complexes were optimized by density functional theory calculations using the GAUSSIAN 03 program package, ${ }^{31}$ with the Becke $^{32}$ three parameter hybrid functional (B3LYP). The calculations were performed using LANL2DZ ${ }^{33}$ basis set for all atoms including tin. The na- 
ture of all stationary points was confirmed by performing a normal- mode analysis. No symmetry constraints were applied in the calculation. Many descriptors were used to recognize and correlate some physical and chemical properties. The most usual descriptors are the highest occupied molecular orbital (HOMO) and lowest unoccupied molecular orbital (LUMO) energies difference between LUMO-HOMO energies. To understand the stability associated these Schiff base Sn(IV) complexes HOMO-LUMO energies for all complexes were calculated. The electronic properties of model compound such as dipole moment, hardness and atomic charges were also computed at the same level of theory. The natural bond orbital (NBO) analysis was obtained with LANL2DZ basis set.

\section{6. Ther Modynamic Studies of Complex for Mation}

The formation constants, $K_{\mathrm{f}}$, of the Sn(IV) complexes were determined by spectrophotometric titration of the ligands with various concentration of the solution of dimethyltin(IV) dichloride at constant ionic strength $(0.1$ $\mathrm{M} \mathrm{NaClO}_{4}$ ) at $25{ }^{\circ} \mathrm{C}$. The interaction of $\mathrm{NaClO}_{4}$ with the ligands was negligible. In a typical measurement, $2.5 \mathrm{~mL}$ of the ligand solution $\left(10^{-5} \mathrm{M}\right)$ in DMF was transferred into the thermostated cell compartment of UV-Visible instrument, and was titrated by the dimethyltin(IV) dichloride solution $\left(10^{-5}-10^{-4} \mathrm{M}\right)$ in DMF.

The titration was performed by adding aliquots of the tin(IV) complex ion with a Hamilton ì syringe to the ligand. The UV-Vis spectra were recorded in the range 290-600 nm about 5 minutes after each addition. The formed product showed different absorption from the free ligand, while the metal complex ion solution shows no absorption at those wavelengths. As an example, the variation of the electronic spectra for $\left(\mathrm{H}_{2} \mathrm{CdacCF}_{3} \mathrm{en}\right)$ titrated with various concentration of dimethyltin(IV) dichloride at $25{ }^{\circ} \mathrm{C}$ in DMF is shown in Figure 1 . The same procedure was followed for other systems. The electronic spectra of the formed complexes at the end of titration were the same as the electronic spectra of the separately synthesized complexes.

\section{Results and Discussion}

The chemical equations concerning the formation of the Schiff base complexes are schematically represented in Scheme 1. Analytical data indicated the formation of metal complexes of ligands $\left(\mathrm{H}_{2} \mathrm{cdacCF}_{3}\right.$ en, $\mathrm{H}_{2}$ cdacacen, $\mathrm{H}_{2}$ cdacPhen, $\mathrm{H}_{2}$ cdacacMeen and $\mathrm{H}_{2}$ cdacacpd) with dimethyltin(IV) dichloride. The physico-chemical properties of the complexes together with their analytical data are shown in Table 1. The elemental analyses data which were in good agreement with the values calculated, indicate that the compositions of the complexes were confirmed to be $\left[\mathrm{SnMe}_{2} \mathrm{Cl}_{2}\left(\mathrm{H}_{2} \mathrm{~L}\right)\right]$. On the other hand, the elemental analysis shows that dimethyltin(IV) dichloride reacts with the ligands in a 1:1 molar ratio to afford the neutral adducts $\left[\mathrm{SnMe}_{2} \mathrm{Cl}_{2}\left(\mathrm{H}_{2} \mathrm{~L}\right)\right]$ where $\mathrm{H}_{2} \mathrm{~L}$ represents the biprotonated form of the ligands $\left(\mathrm{H}_{2} \mathrm{cdacCF}_{3} \mathrm{en}, \mathrm{H}_{2}\right.$ cdacacen, $\mathrm{H}_{2}$ cdacPhen, $\mathrm{H}_{2}$ cdacacMeen and $\mathrm{H}_{2}$ cdacacpd). This is supported by molar conductivity measurements of the complexes in $10^{-3} \mathrm{M}$ DMF.

The molar conductivity values of the complexes are in the range 3.4-8.2 $\Omega^{-1} \mathrm{~cm}^{2} \mathrm{~mol}^{-1}$ (Table 1) indicating the non-electrolytic nature. ${ }^{34,35}$ The low conductivity values are in agreement with low solubility of metal complexes in water, ethanol, chloroform, acetone and some organic solvents.

These compounds are soluble in strong polar solvents such as DMF and DMSO. All the complexes are stable in air. The purity of the complexes has been checked by TLC.

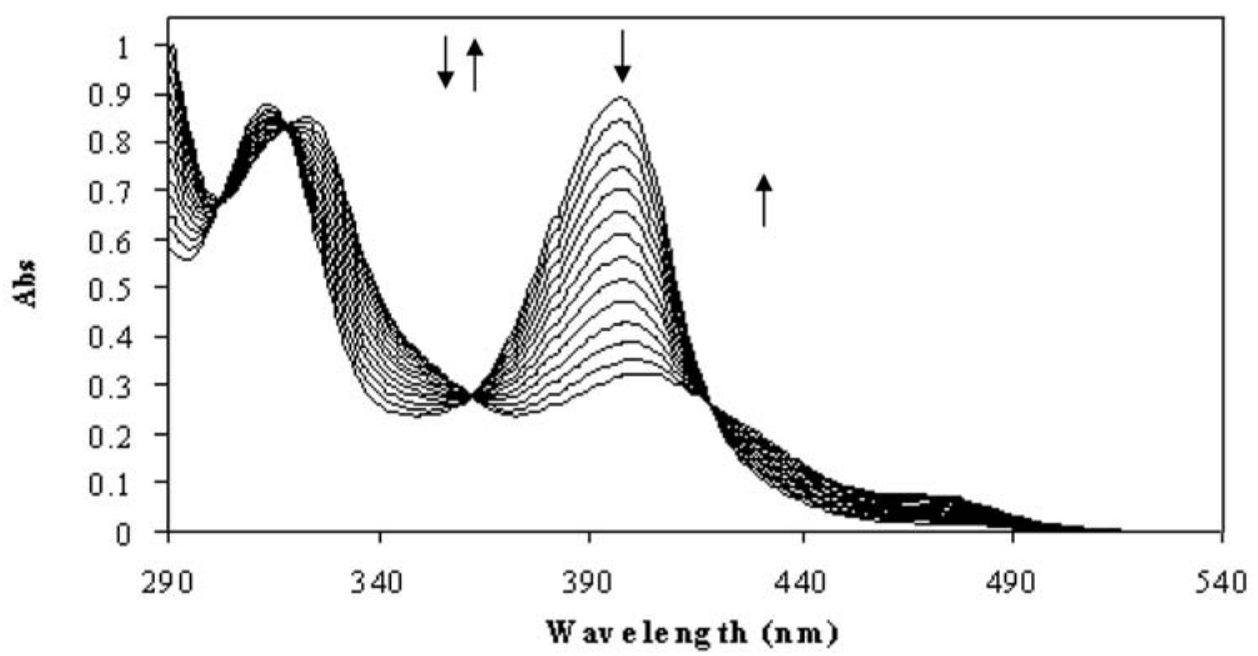

Figure 1. The variation of the electronic spectra of $\left(\mathrm{H}_{2} \mathrm{CdacCF}_{3}\right.$ en $)$ with $\mathrm{Me}_{2} \mathrm{SnCl}_{2}$ in DMF. 


\section{1. IR Spectroscopy}

The mode of binding of ligands to dimethyltin(IV) dichloride was elucidated by recording the IR spectra of the adducts as compared with the spectra of free ligands. In the infrared spectra of free ligands, a band is observed in the region $3000-3200 \mathrm{~cm}^{-1}$ attributable to the stretching vibration of the free $\mathrm{NH}$ or $\mathrm{OH}$, indicating the intramolecular hydrogen bonding in ligand. These bands shift to lower frequencies and overlap with $v(\mathrm{C}-\mathrm{H})$ in the range $2800-3000 \mathrm{~cm}^{-1} \cdot{ }^{26}$ In the IR spectra of tin(IV) complexes, a new band is appeared above $3000 \mathrm{~cm}^{-1}$ attributed to the stretching vibration of $\mathrm{NH}$ in diketons moiety. This is due to the coordination of oxygen atom with tin center, which weakens the hydrogen bonding and so causing more transferring of proton to nitrogen. However, the position of this band indicates that a ring is formed by the intramolecular hydrogen bond in the ligand is retained in adducts. ${ }^{14}$

A strong band at $2739-2762 \mathrm{~cm}^{-1}$ is ascribed to $v(\mathrm{~S}-\mathrm{H})$ existence in the spectra of adducts, confirming sulfur group being still protonated and is not coordination to tin(IV) center. ${ }^{29}$ This is further supported by unchanged $v(\mathrm{C}-\mathrm{S})$ band at $700-750 \mathrm{~cm}^{-1}$ in the ligands and their complexes. ${ }^{5,26,35}$

All ligands show a moderately strong, sharp peak due to $\mathrm{C}=\mathrm{N}$ stretching vibration in the region 1606-1640 $\mathrm{cm}^{-1} \cdot{ }^{36-38}$ After the complexation reactions, the imine $\mathrm{C}=\mathrm{N}$ bands are not shifted at all, indicating that the imine nitrogen atoms are not coordinated to the tin(IV) center.

A strong absorption band in the $1251-1288 \mathrm{~cm}^{-1}$ region in the spectra of the Schiff base ligands can be assigned to the $\mathrm{C}-\mathrm{O}$ stretching. In the complexes, this band is shifted to the $1238-1275 \mathrm{~cm}^{-1}$ upon complexation with the metal which can be attributed to the coordination of the carbonyl oxygen to the metal tin(IV) center., ${ }^{6,39,40}$

New band appearing in the complexes in the low frequency ranges $423-480 \mathrm{~cm}^{-1}$ is due to the $v_{\mathrm{Sn}-\mathrm{O}}$ vibrations and thus confirm the bonding of oxygen to the tin atom as shown in Scheme 1.13,41,42

\section{2. ${ }^{1} \mathrm{H}$ and ${ }^{119}$ Sn NMR}

${ }^{1} \mathrm{H}$ NMR spectra of all the complexes were recorded in DMSO- $d_{6}$ solvent and the data along with assignments are listed in the experimental section. These data exhibits all expected resonance pattern consistent with the proposed structure. The broad signal at $11 \mathrm{ppm}$ is attributable to the resonance of the $\mathrm{N}-\mathrm{H}$ proton in the ketones moiety. Broadening of the signal at $12 \mathrm{ppm}$ indicates the weakening of the $\mathrm{O}-\mathrm{H}$ bond and proton transfer to imine nitrogen. ${ }^{14,15,43}$ The presence of $\mathrm{NH}$ and $\mathrm{OH}$ protons in ${ }^{1} \mathrm{HNMR}$ spectra of the synthesized complexes indicates that the Schiff base ligands are coordinated to tin center in neutral form.

The ligands and their tin(IV) complexes did not show characteristic azomethine proton signal and is not accompanied by ${ }^{119} \mathrm{Sn}$ satellites, revealing the fact that the corresponding nitrogen atom is not coordinated to tin(IV) center. This is in accordance with the IR data. ${ }^{4}$

The peaks observed at the range 7.41-7.88 ppm are assignable to the protons of the aromathic rings as multiplet peaks in $\left[\mathrm{SnMe}_{2} \mathrm{Cl}_{2}\left(\mathrm{H}_{2} \text { cdacPhen }\right)\right]^{23,45}$ The resonances about $5 \mathrm{ppm}$ are consistent with a vinylic hydrogens. ${ }^{37}$

The multiplet signal of diamine alkyl protons in [Sn$\left.\mathrm{Me}_{2} \mathrm{Cl}_{2}\left(\mathrm{H}_{2} \mathrm{cdacCF}_{3} \mathrm{en}\right)\right]$, [ $\mathrm{SnMe}_{2} \mathrm{Cl}_{2}\left(\mathrm{H}_{2}\right.$ cdacacen $\left.)\right]$ and [Sn$\mathrm{Me}_{2} \mathrm{Cl}_{2}\left(\mathrm{H}_{2}\right.$ cdacPhen $\left.)\right]$ were recorded at 3.49-3.74 ppm. ${ }^{46}$ The propyl protons in $\left[\mathrm{SnMe}_{2} \mathrm{Cl}_{2}\left(\mathrm{H}_{2}\right.\right.$ cdacacMeen $\left.)\right]$ and $\left[\mathrm{SnMe}_{2} \mathrm{Cl}_{2}\left(\mathrm{H}_{2}\right.\right.$ cdacacpd $\left.)\right]$ were observed about 1-3 ppm. ${ }^{35}$

Two signals appearing at 1.93 and 2.03, 1.95 and 2.03, 1.98 and 2.05 in [ $\mathrm{SnMe}_{2} \mathrm{Cl}_{2}\left(\mathrm{H}_{2}\right.$ cdacacen $\left.)\right]$, [Sn$\mathrm{Me}_{2} \mathrm{Cl}_{2}\left(\mathrm{H}_{2}\right.$ cdacacMeen $\left.)\right]$ and $\left[\mathrm{SnMe}_{2} \mathrm{Cl}_{2}\left(\mathrm{H}_{2}\right.\right.$ cdacacpd $\left.)\right]$ are corresponded the slightly non-equivalent methyl groups in the acetylacetone moiety. The sharp singlet signal due to the methyl group in $\left[\mathrm{SnMe}_{2} \mathrm{Cl}_{2}\left(\mathrm{H}_{2} \mathrm{cdacCF}_{3} \mathrm{en}\right)\right]$ and [Sn$\left.\mathrm{Me}_{2} \mathrm{Cl}_{2}\left(\mathrm{H}_{2} \mathrm{cdacPhen}\right)\right]$ were observed at 2.30 and $2.12 \mathrm{ppm}$.

The signal attributable to $\mathrm{S}-\mathrm{CH}_{3}(\delta 2.57-2.58)$ in free ligands are not shifted to down field in their tin(IV) complexes indicates no participation of the $\mathrm{C}=\mathrm{S}$ group in bonding. ${ }^{47}$

The complexes exhibited a singlet signal around 1.21-1.27 ppm for $\mathrm{SnMe}_{2}$ protons accompanied by satellites due to ${ }^{1} \mathrm{H}-{ }^{119} \mathrm{Sn}$ coupling. ${ }^{2} J\left({ }^{119} \mathrm{Sn}-{ }^{1} \mathrm{H}\right)$ for these compound $(76.5-90.0 \mathrm{~Hz})$ is larger than original $\mathrm{SnMe}_{2} \mathrm{Cl}_{2}$ $(68.7 \mathrm{~Hz})$ and falls in the range for five coordinated dimethyltin(IV) species. . $^{14,48,49}$

${ }^{119} \mathrm{Sn}$ chemical shift is strongly dependent on the coordination number of tin atom and an increasing in coordination number produces a large upfield shift. ${ }^{50} \mathrm{On}$ the basis of chemical shift ranges proposed empirically for organotin(IV) derivatives, $\delta\left({ }^{119} \mathrm{Sn}\right)$ moves upfield by

Table 1. The analytical data and physical properties of the Sn(IV) Schiff base complexes

\begin{tabular}{|c|c|c|c|c|c|c|c|}
\hline \multirow{2}{*}{ Complexes } & \multirow[t]{2}{*}{ F. W. } & \multirow{2}{*}{$\begin{array}{c}\text { Empirical } \\
\text { formula }\end{array}$} & \multirow{2}{*}{$\begin{array}{c}\text { Molar } \\
\text { conductivity } \\
\left(\Omega^{-1} \mathrm{~cm}^{2} \mathrm{~mol}^{-1}\right)\end{array}$} & \multicolumn{4}{|c|}{ Anal. Found (Calc.)(\%) } \\
\hline & & & & $\mathbf{C}$ & H & $\mathbf{N}$ & $\mathbf{S}$ \\
\hline$\left[\mathrm{SnMe}_{2} \mathrm{Cl}_{2}\left(\mathrm{H}_{2} \mathrm{cdacCF}_{3} \mathrm{en}\right)\right]$ & 572.09 & $\mathrm{C}_{16} \mathrm{H}_{25} \mathrm{~N}_{2} \mathrm{OS}_{2} \mathrm{Cl}_{2} \mathrm{SnF}_{3}$ & $\begin{array}{ll}3 & 8.2\end{array}$ & $33.20(33.59)$ & $4.67(4.40)$ & $5.23(4.90)$ & $10.93(11.21)$ \\
\hline$\left[\mathrm{SnMe}_{2} \mathrm{Cl}_{2}\left(\mathrm{H}_{2}\right.\right.$ cdacacen $\left.)\right]$ & 518.12 & $\mathrm{C}_{16} \mathrm{H}_{28} \mathrm{~N}_{2} \mathrm{OS}_{2} \mathrm{Cl}_{2} \mathrm{Sn}$ & 4.6 & $37.36(37.09)$ & $5.76(5.45)$ & $5.62(5.41)$ & $12.57(12.38)$ \\
\hline$\left[\mathrm{SnMe}_{2} \mathrm{Cl}_{2}\left(\mathrm{H}_{2}\right.\right.$ cdacPhen $\left.)\right]$ & 580.19 & $\mathrm{C}_{21} \mathrm{H}_{30} \mathrm{~N}_{2} \mathrm{OS}_{2} \mathrm{Cl}_{2} \mathrm{Sn}$ & 3.4 & $43.21(43.47)$ & $5.44(5.21)$ & $5.02(4.83)$ & $10.98(11.05)$ \\
\hline$\left[\mathrm{SnMe}_{2} \mathrm{Cl}_{2}\left(\mathrm{H}_{2}\right.\right.$ cdacacMeen $\left.)\right]$ & 532.15 & $\mathrm{C}_{17} \mathrm{H}_{30} \mathrm{~N}_{2} \mathrm{OS}_{2} \mathrm{Cl}_{2} \mathrm{Sn}$ & 4.8 & $38.68(38.37)$ & $5.85(5.68)$ & $5.35(5.26)$ & $12.43(12.05)$ \\
\hline$\left[\mathrm{SnMe}_{2} \mathrm{Cl}_{2}\left(\mathrm{H}_{2}\right.\right.$ cdacacpd $\left.)\right]$ & 532.15 & $\mathrm{C}_{17} \mathrm{H}_{30} \mathrm{~N}_{2} \mathrm{OS}_{2} \mathrm{Cl}_{2} \mathrm{Sn}$ & 4.3 & $38.53(38.37)$ & $5.46(5.68)$ & $5.47(5.26)$ & $11.97(12.05)$ \\
\hline
\end{tabular}


60-150 ppm with a change in the coordination number of tin from 4 to 5 and by $130-200$ ppm from 5 to $6 .^{51,52}$ The ${ }^{119} \mathrm{Sn}\left\{{ }^{1} \mathrm{H}\right\} \mathrm{NMR}$ spectra of the complexes show one sharp singlet significantly at a higher field than those of the original $\mathrm{SnMe}_{2} \mathrm{Cl}_{2}(+137 \mathrm{ppm})$. The chemical shift for these complexes is within the expected range for a five coordination number. ${ }^{50}$

\section{3. Mass Spectra}

The mass spectra of the studied tin(IV) Schiff base complexes were characterized by moderate to high relative intensity molecular ion peaks $m / z[\mathrm{M}]^{+}$(Table 3 ). The mass spectra of some complexes also show prominent peak corresponding to $\mathrm{m} / \mathrm{z},[\mathrm{M}+1]^{+}$. It is obvious that, the molecular ion peaks confirming their suggested empirical formula weights (F. W.) as indicated from elemental analyses respectively (Table 1). The mass spectra show the peaks assigned to $[\mathrm{ML}]^{+}$fragments for the complexes, indicating ligand coordination to the metal atom. The peaks assigned to $\left[\mathrm{ML}_{2}\right]^{+},\left[\mathrm{M}_{2} \mathrm{~L}\right]^{+}$or $\left[\mathrm{M}_{2} \mathrm{~L}_{2}\right]^{+}$fragments could not be detected for any of the complexes, suggesting a mononuclear nature for all of these compounds. For the $\left[\mathrm{SnMe}_{2} \mathrm{Cl}_{2}\left(\mathrm{H}_{2} \mathrm{CdacCF}_{3} \mathrm{en}\right)\right]$, the mass spectrum and the different pathways of the parent molecular ion peaks are given in Figure 2 and Scheme 2.

Table 2. ${ }^{1} \mathrm{H}$ and ${ }^{119} \mathrm{Sn}$ NMR spectral data of the prepared complexes ( $\left.\delta / \mathrm{ppm}\right)$

\begin{tabular}{|c|c|c|c|c|c|c|c|c|}
\hline \multirow{2}{*}{ Complexes } & \multirow[b]{2}{*}{ Sn-Me } & \multicolumn{7}{|c|}{${ }^{1} \mathrm{H}$ NMR } \\
\hline & & $\mathrm{CH}_{3}$ & SMe & H (bridge) & $\mathbf{H}^{\mathbf{a}}$ & NH & $\mathbf{O H}$ & ${ }^{119}$ Sn NMR \\
\hline$\overline{\left[\mathrm{SnMe}_{2} \mathrm{Cl}_{2}\left(\mathrm{H}_{2} \mathrm{cdacCF}_{3} \mathrm{en}\right)\right]}$ & 1.27 & 2.30 & 2.57 & $3.51-3.74$ & 5.61 & 11.64 & 12.43 & -121.73 \\
\hline$\left[\mathrm{SnMe}_{2} \mathrm{Cl}_{2}\left(\mathrm{H}_{2}\right.\right.$ cdacacen $\left.)\right]$ & 1.23 & $1.93,2.03$ & 2.58 & $3.51-3.63$ & 5.03 & 11.03 & 12.43 & -120.12 \\
\hline$\left[\mathrm{SnMe}_{2} \mathrm{Cl}_{2}\left(\mathrm{H}_{2}\right.\right.$ cdacPhen $\left.)\right]$ & 1.25 & 2.12 & 2.58 & $3.49-3.68$ & 5.71 & 11.60 & 12.52 & -123.40 \\
\hline$\left[\mathrm{SnMe}_{2} \mathrm{Cl}_{2}\left(\mathrm{H}_{2}\right.\right.$ cdacacMeen $\left.)\right]$ & 1.22 & $1.95,2.03$ & 2.58 & $1.33,3.40-3.81$ & 5.01 & 11.12 & 12.52 & -127.61 \\
\hline$\left[\mathrm{SnMe}_{2} \mathrm{Cl}_{2}\left(\mathrm{H}_{2}\right.\right.$ cdacacpd $\left.)\right]$ & 1.25 & $1.98,2.05$ & 2.58 & $1.92,3.47,3.53$ & 5.70 & 10.98 & 12.45 & -125.34 \\
\hline
\end{tabular}

Table 3. Important mass spectral data of the Sn(IV) Schiff base complexes

\begin{tabular}{ll}
\hline Complex & $\mathbf{m} / \mathbf{z}$ \\
\hline$\left[\mathrm{SnMe}_{2} \mathrm{Cl}_{2}\left(\mathrm{H}_{2}\right.\right.$ cdacCF & \\
{$\left[\mathrm{SnMe}_{2} \mathrm{Cl}_{2}\left(\mathrm{H}_{2}\right.\right.$ cdacacen $\left.)\right]$} & $572,557,503,297,284,217,128,68,47$ \\
{$\left[\mathrm{SnMe}_{2} \mathrm{Cl}_{2}\left(\mathrm{H}_{2}\right.\right.$ cdacPhen $\left.)\right]$} & $519,518,504,292,245,216,158,68,47$ \\
{$\left[\mathrm{SnMe}_{2} \mathrm{Cl}_{2}\left(\mathrm{H}_{2}\right.\right.$ cdacacMeen $\left.)\right]$} & $580,565,487,283,216,163,111,83,68,47$ \\
{$\left[\mathrm{SnMe}_{2} \mathrm{Cl}_{2}\left(\mathrm{H}_{2}\right.\right.$ cdacacpd $\left.)\right]$} & $533,532,517,487,285,217,188,138,69,47$ \\
\hline
\end{tabular}

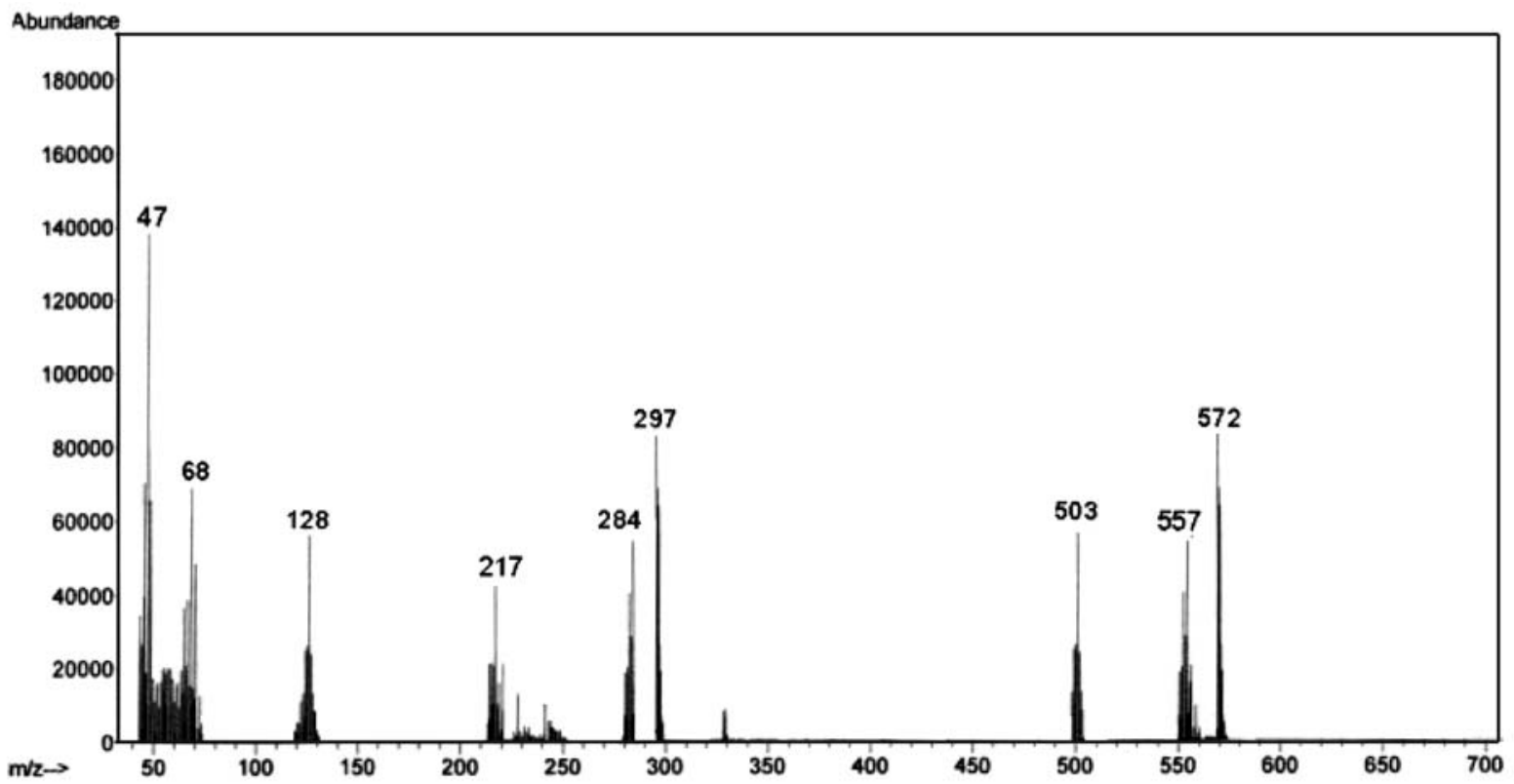

Figure 2. The mass spectrum of the $\left[\mathrm{SnMe}_{2} \mathrm{Cl}_{2}\left(\mathrm{H}_{2} \mathrm{cdacCF}_{3} \mathrm{en}\right]\right.$ 


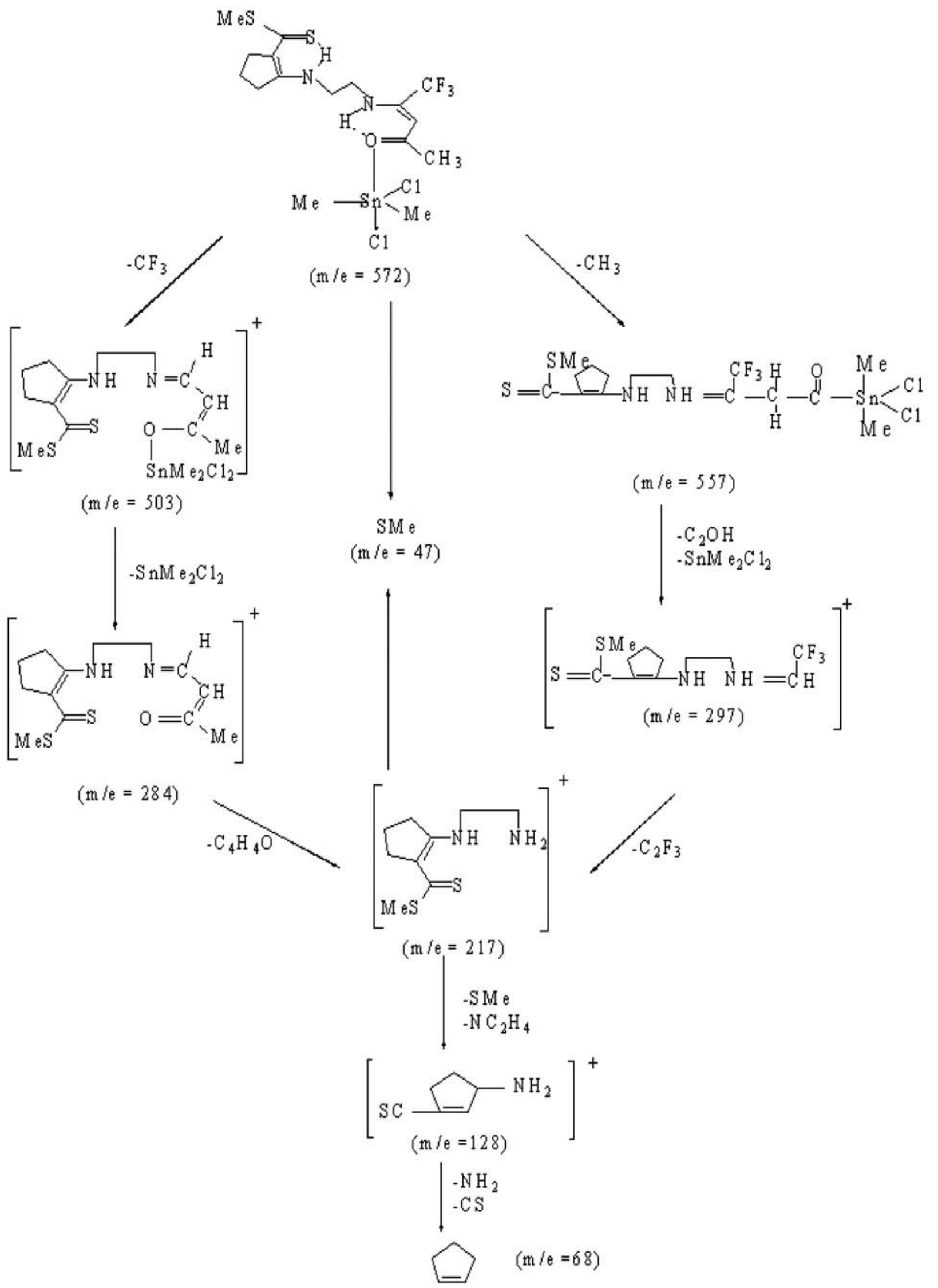

Scheme 2. The schematic diagram mass fragmentation pattern of [ $\mathrm{SnMe}_{2} \mathrm{Cl}_{2}\left(\mathrm{H}_{2} \mathrm{CdacCF}_{3}\right.$ en] 


\section{4. Antibacterial Study}

The antibacterial properties of the tin(IV) Schiff base complexes were evaluated against Gram positive bacteria $(S$. aureus) and Gram negative bacteria $(E$. coli) and are summarized in Table 4 . The results are compared with the standard drug (tetracycline) and indicate that the compounds are active, however, their activity is lower than the standard drug. Our results showed the $\left[\mathrm{SnMe}_{2} \mathrm{Cl}_{2}\left(\mathrm{H}_{2}\right.\right.$ cdacPhen)] could inhibited the growth of $S$. aureus and E. coli compared with tetracycline as control. But, their activity is less than the control drug. It can be noted that the compounds with phenyl groups showed the greatest inhibitory effect on one or more types of bacteria as compared to $\mathrm{Me}$ and $\mathrm{CF}_{3}$ group in the same position. ${ }^{53}$

Table 4. The antibacterial activity data of the Sn(IV) Schiff base complexes

\begin{tabular}{lcc}
\hline Complex & \multicolumn{2}{c}{$\begin{array}{c}\text { Diameter of inhibition } \\
\text { zone }(\mathbf{m m})\end{array}$} \\
& $\boldsymbol{E}$. Coli & S. Aureus \\
\hline Tetracycline & 32 & 34 \\
{$\left[\mathrm{SnMe}_{2} \mathrm{Cl}_{2}\left(\mathrm{H}_{2}\right.\right.$ cdacCF $_{3}$ en $\left.)\right]$} & 12 & 16 \\
{$\left[\mathrm{SnMe}_{2} \mathrm{Cl}_{2}\left(\mathrm{H}_{2}\right.\right.$ cdacacen $\left.)\right]$} & 18 & 18 \\
$\left[\mathrm{SnMe}_{2} \mathrm{Cl}_{2} \mathrm{H}_{2}\right.$ cdacPhen $\left.)\right]$ & 20 & 23 \\
{$\left[\mathrm{SnMe}_{2} \mathrm{Cl}_{2}\left(\mathrm{H}_{2}\right.\right.$ cdacacMeen $\left.)\right]$} & 18 & 20 \\
{$\left[\mathrm{SnMe}_{2} \mathrm{Cl}_{2}\left(\mathrm{H}_{2}\right.\right.$ cdacacpd $\left.)\right]$} & 13 & 17 \\
\hline
\end{tabular}

\section{5. The Formation Constants}

To interpret the steric and the electronic parameters of the ligands on the formation constants, the interaction between five ligands $\left(\mathrm{H}_{2}\right.$ cdacacen, $\mathrm{H}_{2} \mathrm{cdacCF}_{3}$ en, $\mathrm{H}_{2}$ cdacPhen, $\mathrm{H}_{2}$ cdacacMeen, $\mathrm{H}_{2}$ cdacacpd) and dimethyltin(IV) dichloride $\left(\mathrm{Me}_{2} \mathrm{SnCl}_{2}\right)$ was carried out by UV-Vis absorption spectroscopy through titration of the ligands with various concentrations of the $\mathrm{Sn}(\mathrm{IV})$ complex ion at $25^{\circ} \mathrm{C}$. The complex formation constants, $K_{\mathrm{f}}$, were calculated using SQUAD computer program, ${ }^{54}$ designed to calculate the best values for the formation constants of the proposed equation model (Eq. 1) by employing a non-linear, leastsquares approach:

$$
\mathrm{Me}_{2} \mathrm{SnCl}_{2}+\mathrm{H}_{2} \mathrm{~L} \rightarrow\left[\mathrm{Me}_{2} \mathrm{SnCl}_{2} \cdot \mathrm{H}_{2} \mathrm{~L}\right]
$$

where $\mathrm{H}_{2} \mathrm{~L}=\mathrm{H}_{2}$ cdacacen, $\mathrm{H}_{2}$ cdacCF$_{3}$ en, $\mathrm{H}_{2}$ cdacPhen, $\mathrm{H}_{2}$ cdacacMeen and $\mathrm{H}_{2}$ cdacacpd.

Also, the free energy change, $\Delta G^{\circ}$, of the complexes were determined by $\Delta G^{\circ}=-R T \ln K_{\mathrm{f}}$, at $25^{\circ} \mathrm{C}$ (Table 5). The results show the following trend of complex formation of $\mathrm{Sn}(\mathrm{IV})$ compound with the Schiff bases (Table 5):

$$
\left.\left(\mathrm{H}_{2} \text { cdacacen }\right)>\left(\mathrm{H}_{2} \mathrm{cdacCF}_{3} \text { en }\right)>\left(\mathrm{H}_{2} \text { cdacPhen }\right)\right]
$$

This is somewhat in agreement with decreasing electron-releasing character of the substituents in the sa- me direction. The withdrawing functional groups $\left(\mathrm{CF}_{3}\right)$ and $(\mathrm{Ph})$ make the Schiff base as a poor donor ligand and decrease the stability of complexes while the electron donor group $\left(\mathrm{CH}_{3}\right)$ increasing the stability because they leads to increase the donor ability of Schiff base ligands. With respect to the steric effect, the greater the bulkiness of the phenyl ring in $\mathrm{H}_{2}$ cdacPhen, the less is the formation constants (compare $\mathrm{CF}_{3}$ and $\mathrm{CH}_{3}$ ), so the decrease in formation constants was seen. Meanwhile, the stability of the tin(IV) complex with the used different bridge decreases according to the following sequence:

$$
\left(\mathrm{H}_{2} \text { cdacacMeen }\right)>\left(\mathrm{H}_{2} \text { cdacacen }\right)>\left(\mathrm{H}_{2} \text { cdacacpd }\right)
$$

The propylene derivative is considered to produce a weaker ligand field than the ethylene derivative, since the strain is caused by the propylene chain on complex formation. Therefore, $\mathrm{H}_{2}$ cdacacpd must produce a weaker ligand field than $\mathrm{H}_{2}$ cdacacen and $\mathrm{H}_{2}$ cdacacMeen, and formation constant, $K_{\mathrm{f}}$, for $\left[\mathrm{SnMe}_{2} \mathrm{Cl}_{2}\left(\mathrm{H}_{2}\right.\right.$ cdacacpd)] is smaller than $\left[\mathrm{SnMe}_{2} \mathrm{Cl}_{2}\left(\mathrm{H}_{2}\right.\right.$ cdacacMeen $\left.)\right]$ and $\left[\mathrm{SnMe}_{2} \mathrm{Cl}_{2}\right.$ $\left(\mathrm{H}_{2}\right.$ cdacacen $)$ ]. The formation constants and the free energy data for $\left[\mathrm{SnMe}_{2} \mathrm{Cl}_{2}\left(\mathrm{H}_{2}\right.\right.$ cdacacMeen $\left.)\right]$ is larger than those for $\left[\mathrm{SnMe}_{2} \mathrm{Cl}_{2}\left(\mathrm{H}_{2}\right.\right.$ cdacacen $\left.)\right]$. It was observed that the addition of methyl group to Schiff base ligand increases the formation constant of the complexes. Similar results have been reported previously for the electrochemical properties of the analogous $\mathrm{Cu}(\mathrm{II}), \mathrm{Ni}(\mathrm{II})$ and $\mathrm{Co}(\mathrm{III})$ systems. ${ }^{24,25,27}$

\begin{tabular}{|c|c|c|}
\hline Complexes & $\log K_{f}$ & $\Delta G^{\circ}\left(\mathrm{kJmol}^{-1}\right)^{\mathrm{b}}$ \\
\hline$\left[\mathrm{SnMe}_{2} \mathrm{Cl}_{2}\left(\mathrm{H}_{2} \mathrm{cdacCF}_{3} \mathrm{en}\right)\right]$ & $7.41(0.14)^{\mathrm{a}}$ & $-42.26(0.34)$ \\
\hline$\left[\mathrm{SnMe}_{2} \mathrm{Cl}_{2}\left(\mathrm{H}_{2}\right.\right.$ cdacacen $\left.)\right]$ & $7.63(0.17)$ & $-43.51(0.42)$ \\
\hline$\left[\mathrm{SnMe}_{2} \mathrm{Cl}_{2}\left(\mathrm{H}_{2}\right.\right.$ cdacPhen $\left.)\right]$ & $7.32(0.08)$ & $-41.74(0.19)$ \\
\hline$\left[\mathrm{SnMe}_{2} \mathrm{Cl}_{2}\left(\mathrm{H}_{2}\right.\right.$ cdacacMeen $\left.)\right]$ & $7.98(0.18)$ & $-45.51(0.44)$ \\
\hline$\left[\mathrm{SnMe}_{2} \mathrm{Cl}_{2}\left(\mathrm{H}_{2}\right.\right.$ cdacacpd $\left.)\right]$ & $7.21(0.12)$ & $-41.12(0.28)$ \\
\hline
\end{tabular}

Table 5. The formation constants, $\log K_{\mathrm{f}}$, and the free energy values $\left(\Delta G^{\circ}\right.$ ) of tin (IV) complexes at $25^{\circ} \mathrm{C}$ in DMF

${ }^{\mathrm{a}}$ The numbers in parentheses are the standard deviations.

${ }^{\mathrm{b}} \Delta G=-R T \ln K_{\mathrm{f}}$

\section{6. DFT Optimized Structures}

Theoretical investigations have much applicability in investigation of chemical reactions and identification of the chemical compounds. They could be considered as complementary to or replacement for experimental methods. The fully optimized molecular structure of the $\left[\mathrm{Me}_{2} \mathrm{SnCl}_{2} \cdot \mathrm{H}_{2} \mathrm{cdacCF}_{3}\right.$ en] with atomic numbering is shown in Figure 3 and for other complexes are given in supplementary material (Figure S1). These complexes have a nearly trigonal bipyramidal (tbp) geometry with two $\mathrm{C}$ atoms of the $\mathrm{CH}_{3}$ group and the $\mathrm{Cl}$ atom in the equatorial position, while one of the $\mathrm{Cl}$ atoms and the $\mathrm{O}$ 
atom of the Schiff base ligand remains above and below the plane (apical or axial position), they are at $180^{\circ}$ to each other and at $90^{\circ}$ to the equatorial atoms. The DFT calculated $\mathrm{C} 1-\mathrm{Sn}-\mathrm{C} 2, \mathrm{Cl} 2-\mathrm{Sn}-\mathrm{C} 1, \mathrm{Cl} 2-\mathrm{Sn}-\mathrm{C} 2$ (around $120^{\circ}$ ) and $\mathrm{O}-\mathrm{Sn}-\mathrm{Cl} 2, \mathrm{Cl} 1-\mathrm{Sn}-\mathrm{Cl} 2$ (around $90^{\circ}$ ) angles is very close to tbp geometry. Some important optimized bond angles were listed in Table 6 .

In the optimized structure of the tin(IV) complexes, ketones moieties and the cyclopentene rings are not in the same plane, but their planes make approximately a $20^{\circ} \mathrm{di}-$ hedral angle to each other. The calculated dihedral angles

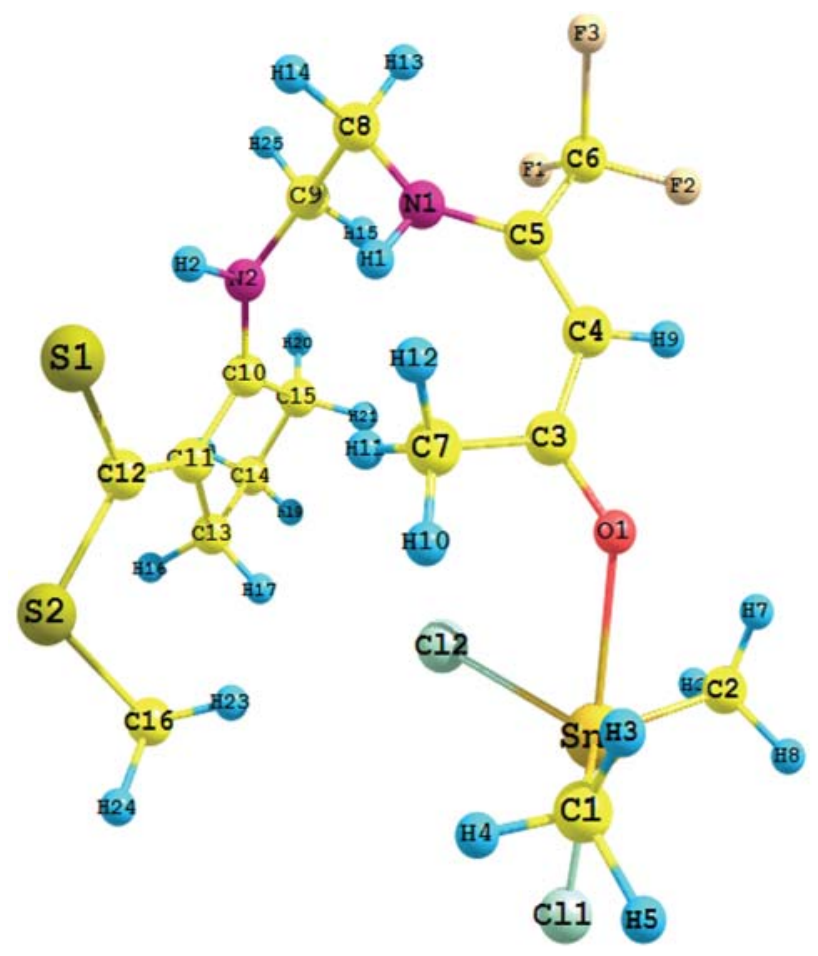

Figure 3. The optimized structures of the $\left[\mathrm{SnMe}_{2} \mathrm{Cl}_{2}\left(\mathrm{H}_{2} \mathrm{cdac}-\right.\right.$ $\mathrm{CF}_{3}$ en)]
$\mathrm{N} 1-\mathrm{C} 4-\mathrm{N} 2-\mathrm{C} 11$ and $\mathrm{C} 3-\mathrm{O} 1-\mathrm{C} 12-\mathrm{S} 1$ in $\left[\mathrm{SnMe}_{2} \mathrm{Cl}_{2}\right.$ $\left(\mathrm{H}_{2}\right.$ cdacCF $\mathrm{CF}_{3}$ en $)$, $\left[\mathrm{SnMe}_{2} \mathrm{Cl}_{2}\left(\mathrm{H}_{2}\right.\right.$ cdacacen $\left.)\right],\left[\mathrm{SnMe}_{2} \mathrm{Cl}_{2}\right.$ ( $\mathrm{H}_{2}$ cdacacMeen)] and N1-C4-N2-C10, C3-O1-C11-S1 in $\left[\mathrm{SnMe}_{2} \mathrm{Cl}_{2}\left(\mathrm{H}_{2} \mathrm{cdacPhen}\right)\right]$ are $(-34.53,-150.32)$, $(-32.27,-149.144),(-46.58,-150.34)$ and $(-65.49$, $-178.23)$, respectively. On the basis of these results, these complexes are twisted. Some responsible factors will be represented later by NBO analyses.

As can be seen from Table 7, the calculated $\mathrm{Sn}-\mathrm{O}$ and $\mathrm{Sn}-\mathrm{Cl1}$ bond lengths in the axial position are greater than the $\mathrm{Sn}-\mathrm{C} 1, \mathrm{Sn}-\mathrm{C} 2, \mathrm{Sn}-\mathrm{Cl} 2$ bond lengths in equatorial position, these is in excellent agreement with the tbp structure. The axial bonds in tbp complexes are then not longer (as usual) than the equatorial bonds. On the other hand, bond distance between two atoms is affected by neighboring functional groups in the structure. Although in these structures, differences of the length of bond are little, we compared some important bond lengths of these complexes. If the $\mathrm{CH}_{3}$ on the carbon atom of $\mathrm{C}=\mathrm{N}$ group is replaced by a $\mathrm{CF}_{3}$ and $\mathrm{Ph}$ group in $\left[\mathrm{SnMe}_{2} \mathrm{Cl}_{2}\left(\mathrm{H}_{2} \mathrm{cdac}-\right.\right.$ $\mathrm{CF}_{3}$ en $\left.)\right]$ and $\left[\mathrm{SnMe}_{2} \mathrm{Cl}_{2}\left(\mathrm{H}_{2}\right.\right.$ cdacPhen $\left.)\right]$ complexes, there is a steric effect and the electronic effect comprising the other complexes is lifted. The withdrawing groups $\left(\mathrm{CF}_{3}\right.$ and phenyl) causes a decreases of the density of electron along carbon bonds while the methyl group is a donating group and increase electron density along carbon bonds. However, the two $\mathrm{Sn}-\mathrm{N}$ bond lengths are different significantly.

The electronic parameters of tin(IV) Schiff base complexes optimized in the ground state configuration were summarized in Table 8 . To understand the stability of these complexes, we had calculated the highest occupied molecular orbital-lowest unoccupied molecular orbital (HOMO-LUMO) gap for all these complexes (Table 8). The corresponding density plots of HOMO and LU$\mathrm{MO}$ for $\left[\mathrm{Me}_{2} \mathrm{SnCl}_{2} \cdot \mathrm{H}_{2} \mathrm{cdacCF}_{3} \mathrm{en}\right]$ complex obtained from their optimized geometries is visualized in Figure 4 and for other complexes can be seen in supplementary material (Figure S2). The HOMO surface is mostly locali-

Table 6. The selected bond angles $\left(^{\circ}\right.$ ) of $\mathrm{Sn}(\mathrm{IV})$ complexes (labels for atoms can be found in Figures 3 and S1)

\begin{tabular}{|c|c|c|c|c|c|c|}
\hline angle & Cl1-Sn-Cl2 & $\mathrm{C1}-\mathrm{Sn}-\mathrm{C2}$ & O1-Sn-Cl1 & O1-Sn-Cl2 & $\mathrm{Cl2}-\mathrm{Sn}-\mathrm{C2}$ & Cl2-Sn-C1 \\
\hline$\left[\mathrm{SnMe}_{2} \mathrm{Cl}_{2}\left(\mathrm{H}_{2} \mathrm{cdacCF}_{3} \mathrm{en}\right)\right]$ & 95.776 & 129.551 & 179.234 & 79.413 & 111.993 & 113.697 \\
\hline$\left[\mathrm{SnMe}_{2} \mathrm{Cl}_{2}\left(\mathrm{H}_{2}\right.\right.$ cdacacen $\left.)\right]$ & 93.990 & 129.910 & 180.023 & 81.483 & 112.200 & 115.349 \\
\hline$\left[\mathrm{SnMe}_{2} \mathrm{Cl}_{2}\left(\mathrm{H}_{2}\right.\right.$ cdacPhen $\left.)\right]$ & 96.226 & 129.980 & 179.231 & 82.961 & 114.027 & 113.012 \\
\hline$\left[\mathrm{SnMe}_{2} \mathrm{Cl}_{2}\left(\mathrm{H}_{2}\right.\right.$ cdacacMeen $\left.)\right]$ & 93.803 & 129.741 & 180.021 & 81.394 & 112.798 & 115.013 \\
\hline
\end{tabular}

Table 7. The selected bond lengths ( $\AA$ ) of Sn(IV) complexes (labels for atoms can be found in Figures 3 and S1)

\begin{tabular}{|c|c|c|c|c|c|c|}
\hline Complexes & Sn-O & Sn-Cl1 & $\mathrm{Sn}-\mathrm{Cl} 2$ & Sn-C1 & $\mathrm{Sn}-\mathrm{C2}$ & C5-C6 \\
\hline$\left[\mathrm{SnMe}_{2} \mathrm{Cl}_{2}\left(\mathrm{H}_{2} \mathrm{cdacCF}_{3} \mathrm{en}\right)\right]$ & 2.471 & 2.468 & 2.222 & 2.124 & 1.123 & 1.576 \\
\hline$\left[\mathrm{SnMe}_{2} \mathrm{Cl}_{2}\left(\mathrm{H}_{2}\right.\right.$ cdacacen $\left.)\right]$ & 2.494 & 2.488 & 2.212 & 2.122 & 1.122 & 1.532 \\
\hline$\left[\mathrm{SnMe}_{2} \mathrm{Cl}_{2}\left(\mathrm{H}_{2}\right.\right.$ cdacPhen $\left.)\right]$ & 2.461 & 2.464 & 2.223 & 2.123 & 1.124 & 1.565 \\
\hline$\left[\mathrm{SnMe}_{2} \mathrm{Cl}_{2}\left(\mathrm{H}_{2}\right.\right.$ cdacacMeen $\left.)\right]$ & 2.495 & 2.499 & 2.216 & 2.122 & 1.123 & 1.534 \\
\hline
\end{tabular}


zed on the imine side for all complexes. In the surface shown for the HOMO level, the N2-CX group is overlapped $\left(\mathrm{CX}=\mathrm{C} 10\right.$ in $\left[\mathrm{SnMe}_{2} \mathrm{Cl}_{2}\left(\mathrm{H}_{2} \mathrm{CdacCF}_{3} \mathrm{en}\right)\right]$ and $[\mathrm{Sn}$ $\mathrm{Me}_{2} \mathrm{Cl}_{2}\left(\mathrm{H}_{2}\right.$ cdacacen $\left.)\right], \mathrm{CX}=\mathrm{C} 9$ in $\left[\mathrm{SnMe}_{2} \mathrm{Cl}_{2}\left(\mathrm{H}_{2}\right.\right.$ cdacPhen $)]$ and $\mathrm{CX}=\mathrm{C} 11$ in $\left[\mathrm{SnMe}_{2} \mathrm{Cl}_{2}\left(\mathrm{H}_{2}\right.\right.$ cdacacMeen $\left.)\right]$ ). The LUMO surface of the complexes mostly localized within the Sn side, and for the HOMO level, the O-C3 group is overlapped. In [ $\mathrm{SnMe}_{2} \mathrm{Cl}_{2}\left(\mathrm{H}_{2}\right.$ cdacPhen $\left.)\right]$ complex the LUMO surface is localized on the aromatic ring.

The HOMO-LUMO gap is used as a direct indicator of stability. ${ }^{55-58}$ A large HOMO-LUMO gap increases stability and decreases chemical reactivity. The results show the following trend in HOMO-LUMO gap for the complexes: $\left[\mathrm{SnMe}_{2} \mathrm{Cl}_{2}\left(\mathrm{H}_{2}\right.\right.$ cdacacMeen $\left.)\right]>\left[\mathrm{SnMe}_{2} \mathrm{Cl}_{2}\right.$
$\left(\mathrm{H}_{2}\right.$ cdacacen $\left.)\right]$

and

$\left[\mathrm{SnMe}_{2} \mathrm{Cl}_{2}\left(\mathrm{H}_{2}\right.\right.$ cdaccen $\left.)\right]>\left[\mathrm{SnMe}_{2} \mathrm{Cl}_{2}\left(\mathrm{H}_{2} \mathrm{CdacCF}_{3}\right.\right.$ en $\left.)\right]$ $<\left[\mathrm{SnMe}_{2} \mathrm{Cl}_{2}\left(\mathrm{H}_{2}\right.\right.$ cdaPhen $\left.)\right]$

The $\left[\mathrm{SnMe}_{2} \mathrm{Cl}_{2}\left(\mathrm{H}_{2}\right.\right.$ cdacPhen $\left.)\right]$ have a small gap between all the complexes and is less stable than other com- plexes. The charge donation from Schiff base $\mathrm{n}$ and $\pi$ molecular orbital into $\mathrm{Sn}(\mathrm{IV})$ atom is increased by electron donating groups on the Schiff base ligands. Thus, the stability of complexes decreases according to the sequence acacMeen $>$ acacen $>\mathrm{acCF}_{3}$ en $>$ acPhen and $\mathrm{CH}_{3}>\mathrm{Ph}>$ $\mathrm{CF}_{3}$ i.e. in order of a decrease in both electron-withdrawing and $\pi$-acceptor qualities of the substituents and the acceptor ability of the ligand Schiff base groups. The DFT calculations support the experimental formation constant and stability of complexes.

Stability of the molecule arising from hyper conjugative interactions and charge delocalization has been analyzed using natural bond orbital analysis (NBO). The optimized structures of the title compounds were employed for NBO analysis at B3LYP/LANL2DZ level in gasphase.

A useful aspect of the NBO method is that it gives information about interactions in both filled and virtual orbital spaces that could enhance the analysis of intra and intermolecular interaction. This delocalization of electron density between occupied Lewis-orbital (bond or lone pair) and non-Lewis unoccupied (anti-bonding) orbital, correspond to a stabilizing donor-acceptor interaction. In the NBO analysis, for each donor NBO (i) and acceptor
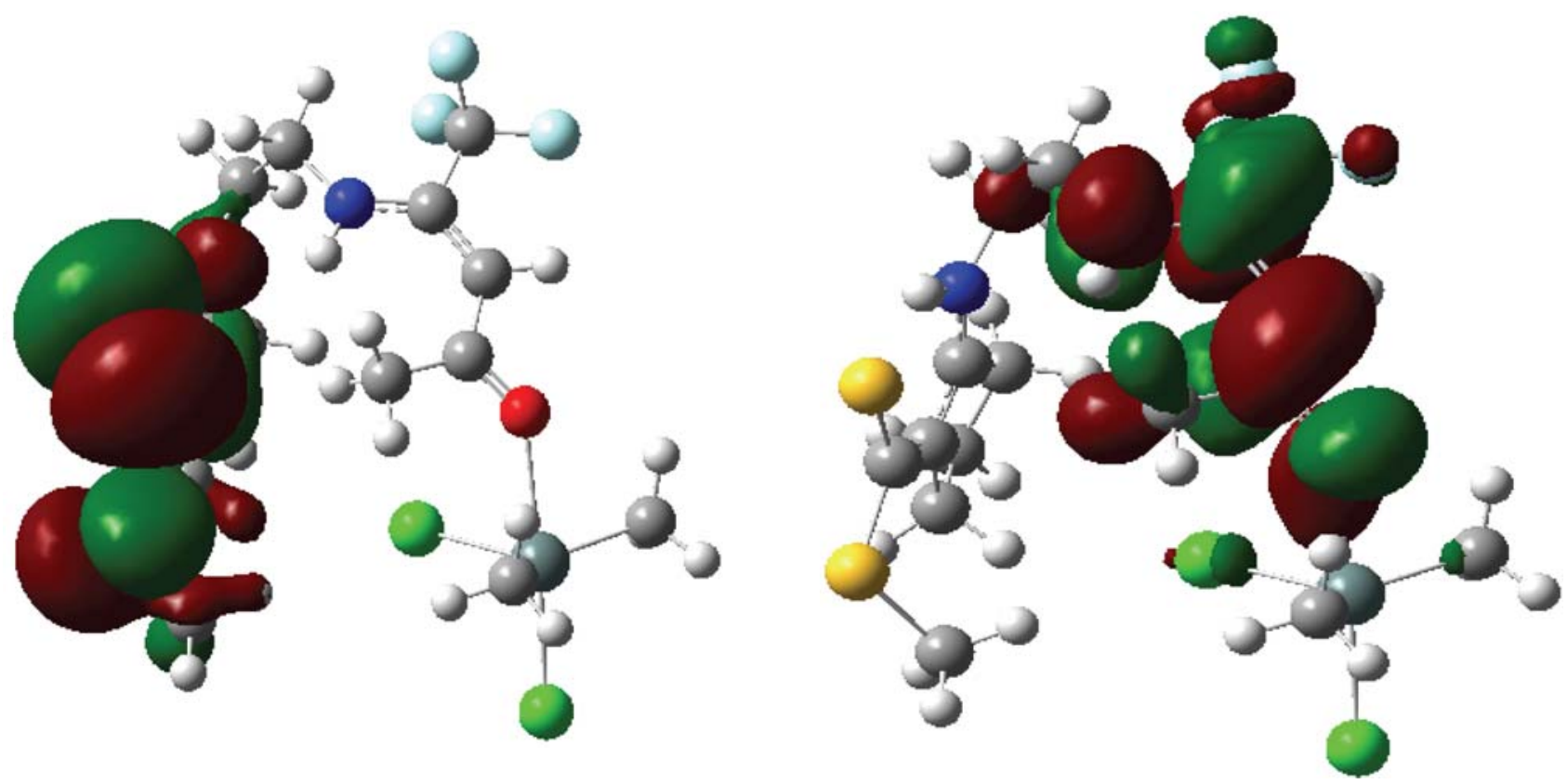

Figure 4. $\mathrm{HOMO}$ (left) and LUMO (right) orbital of $\left[\mathrm{SnMe}_{2} \mathrm{Cl}_{2}\left(\mathrm{H}_{2} \mathrm{cdacCF}_{3}\right.\right.$ en) $]$

Table 8. The computed electronic properties of Sn(IV) complexes with B3LYP/LANL2DZ.

\begin{tabular}{lcccr}
\hline Complexes & HOMO/eV & LUMO/eV & gap/eV & Dipole/ Debye \\
\hline$\left[\mathrm{SnMe}_{2} \mathrm{Cl}_{2}\left(\mathrm{H}_{2} \mathrm{cdacCF}_{3} \mathrm{en}(]\right.\right.$ & -0.2033 & -0.1194 & 0.084 & 8.36 \\
{$\left[\mathrm{SnMe}_{2} \mathrm{Cl}_{2}\left(\mathrm{H}_{2}\right.\right.$ cdacacen $\left.)\right]$} & -0.1990 & -0.1136 & 0.085 & 14.01 \\
{$\left[\mathrm{SnMe}_{2} \mathrm{Cl}_{2}\left(\mathrm{H}_{2}\right.\right.$ cdacPhen $\left.)\right]$} & -0.2054 & -0.1224 & 0.083 & 21.00 \\
{$\left[\mathrm{SnMe}_{2} \mathrm{Cl}_{2}\left(\mathrm{H}_{2}\right.\right.$ cdacacMeen $\left.)\right]$} & -0.1919 & -0.0913 & 0.101 & 14.28 \\
\hline
\end{tabular}


(j), the stabilization energy $E(2)$ associated with the delocalization $(\mathrm{i} \rightarrow \mathrm{j})$ is estimated as:

$$
\mathrm{E}(2)=\Delta \mathrm{E}_{\mathrm{ij}}=\Delta \mathrm{E}_{\mathrm{CT}}=\frac{\mid\langle\mathrm{i}|\hat{\mathrm{F}}| \mathrm{j}|}{\varepsilon_{\mathrm{j}}-\varepsilon_{\mathrm{i}}}
$$

where $\varepsilon$ and $\varepsilon$ are NBO orbital energies, and $\hat{\mathrm{F}}$ is the Fock operator.

The quantities of transferred charge from a given donor orbital to a given acceptor orbital $\left(\mathrm{q}_{\mathrm{CT}}\right)$ may be estimated again using the perturbation theory arguments, leading to the following approximate formula.

$$
\mathrm{q}_{\mathrm{CT}} \approx \frac{\left|\Delta \mathrm{E}_{\mathrm{CT}}\right|}{\varepsilon_{\mathrm{j}}-\varepsilon_{\mathrm{i}}}
$$

In Table 9, the perturbation energies of signi $\rightarrow$ ant donor-acceptor interactions of Sn(IV) complexes are presented. The results show intramolecular charge transfer (ICT) causing stabilization of the system. The most important interactions in the Sn complexes are the charge donation from $n$ molecular orbital of Schiff base ligand into the $\mathrm{Sn}(\mathrm{IV})$ center, that is presented in Table 8 for each complex.

That sum of stabilization energy and charge transfer shown for each complex in the same table.

The results show the following trend:

$\left[\mathrm{SnMe}_{2} \mathrm{Cl}_{2}\left(\mathrm{H}_{2}\right.\right.$ cdacacMeen $\left.)\right]>\left[\mathrm{SnMe}_{2} \mathrm{Cl}_{2}\right.$ $\left(\mathrm{H}_{2}\right.$ cdacacen $\left.)\right]>\left[\mathrm{SnMe}_{2} \mathrm{Cl}_{2}\left(\mathrm{H}_{2} \mathrm{CdacCF}_{3}\right.\right.$ en $\left.)\right]>$ $\left[\mathrm{SnMe}_{2} \mathrm{Cl}_{2}\left(\mathrm{H}_{2}\right.\right.$ cdacPhen $\left.)\right]$
These results indicate of the stability of complexes decreases according to the sequence $\mathrm{CH}_{3}>\mathrm{CF}_{3}>\mathrm{Ph}$. The charge donation from Schiff base $\mathrm{n}$ and $\pi$ molecular orbital into $\mathrm{Sn}(\mathrm{IV})$ atom is increased by electron releasing groups on the Schiff base ligands.

The electric dipole moment is a measurement of the separation of positive and negative electrical charges in a system. The trend of electric dipole moment of the tin(IV) complexes decreases as follow:

$$
\begin{aligned}
& {\left[\mathrm{SnMe}_{2} \mathrm{Cl}_{2}\left(\mathrm{H}_{2} \mathrm{cdacPhen}\right)\right]>\left[\mathrm{SnMe}_{2} \mathrm{Cl}_{2}\right.} \\
& \left(\mathrm{H}_{2} \mathrm{cdacacMeen}_{2}\right]>\left[\mathrm{SnMe}_{2} \mathrm{Cl}_{2}\left(\mathrm{H}_{2} \text { cdacacen }\right)\right]> \\
& {\left[\mathrm{SnMe}_{2} \mathrm{Cl}_{2}\left(\mathrm{H}_{2} \mathrm{cdacCF} \mathrm{CH}_{3} \text { en }\right)\right]}
\end{aligned}
$$

\section{Conclusion}

This paper describes the synthesis of five new unsymmetrical Schiff base tin(IV) complexes. Then, these complexes have been characterized by several spectroscopic methods. The analytical results show 1:1 metal:ligand stoichiometry. The spectral data show that the complexation takes place through oxygen atom. The complexes were screened against various bacteria to access their potential as antibacterial agents. The geometry of the complexes were optimized with DFT calculations using the GAUSSIAN 03 program package, with the Becke three parameter hybrid functional (B3LYP). The calculations were performed using LANL2DZ basis set for all atoms including tin. The stability of these complexes has been

\begin{tabular}{|c|c|c|c|c|c|c|c|}
\hline \multicolumn{4}{|c|}{$\left[\mathrm{SnMe}_{2} \mathrm{Cl}_{2}\left(\mathrm{H}_{2}\right.\right.$ cdacacMeen $\left.)\right]$} & \multicolumn{4}{|c|}{$\left[\mathrm{SnMe}_{2} \mathrm{Cl}_{2}\left(\mathrm{H}_{2}\right.\right.$ cdacPhen $\left.)\right]$} \\
\hline Donor (i) & Acceptor (j) & $E(2)(\mathrm{kJ} / \mathrm{mol})$ & $\left(\mathbf{q}_{\mathrm{CT}}\right)$ & Donor (i) & Acceptor (j) & $E(2)(\mathrm{kJ} / \mathrm{mol})$ & $\left(\mathbf{q}_{\mathrm{CT}}\right)$ \\
\hline$\pi_{S n-C 1}$ & $\pi_{S n-C 2}^{*}$ & 10.27 & 0.028 & $\pi_{S n-C 1}$ & $\pi_{S n}^{*}$ & 5.03 & 0.016 \\
\hline$\pi_{S n-C 2}$ & $\pi_{S n-C 1}^{*}$ & 10.48 & 0.029 & $\pi_{S n-C 1}$ & $\pi_{S}^{*}$ & 5.43 & 0.014 \\
\hline$n_{S n}^{*}$ & $\pi_{S n-C 1}^{* n-C 1}$ & 14.78 & 0.139 & $\pi_{S n-C l 1}$ & $\pi^{*}{ }_{S}$ & 4.53 & 0.012 \\
\hline \multirow[t]{2}{*}{$n_{S n}^{*}$} & $\pi_{S n-C 2}^{*}$ & 13.93 & 0.131 & $\pi_{S n-C l 1}$ & $\pi_{S t}^{*}$ & 4.94 & 0.013 \\
\hline & & & & $\pi_{S n-C l 2}$ & $\pi_{S n-C l 1}^{*}$ & 4.27 & 0.012 \\
\hline SUM & & 49.46 & 0.326 & SUM & & 24.20 & 0.060 \\
\hline \multirow[b]{2}{*}{ Donor (i) } & {$\left[\mathrm{SnMe}_{2} \mathrm{Cl}\right.$} & lacacen)] & & \multicolumn{4}{|c|}{$\left[\mathrm{SnMe}_{2} \mathrm{Cl}_{2}\left(\mathrm{H}_{2} \mathrm{cdacCF}_{3} \mathrm{en}\right)\right]$} \\
\hline & Acceptor (j) & $E(2)(\mathrm{kJ} / \mathrm{mol})$ & $\left(\mathbf{q}_{\mathrm{CT}}\right)$ & Donor (i) & Acceptor (j) & $E(2)(\mathrm{kJ} / \mathrm{mol})$ & $\left(\mathbf{q}_{\mathrm{CT}}\right)$ \\
\hline$\pi_{S n-C 1}$ & $\pi_{S n-C 2}^{*}$ & 9.76 & 0.027 & $\pi_{S n-C 1}$ & $\pi_{S l}^{*}$ & 5.38 & 0.014 \\
\hline$\pi_{S n-C 2}$ & $\pi_{S n-C 1}^{*}$ & 9.62 & 0.026 & $\pi_{S n-C 1}$ & $\pi_{S t}^{*}$ & 5.00 & 0.016 \\
\hline$n_{S n}^{*}$ & $\pi_{S n-C 1}^{*}$ & 14.48 & 0.136 & $\pi_{S n-C 2}$ & $\pi_{S t}^{*}$ & 5.43 & 0.014 \\
\hline$n_{S n}^{*}$ & $\pi_{S n-C 2}^{* n-C 1}$ & 14.48 & 0.136 & $\pi_{S n-C 2}^{S n-22}$ & $\pi_{S n}^{*}$ & 5.28 & 0.017 \\
\hline & & & & $\pi_{S n-C 2}$ & $\pi_{S}^{*}$ & 4.32 & 0.013 \\
\hline & & & & $\pi_{S n-C 2}$ & $\pi^{*}$ & 4.53 & 0.012 \\
\hline & & & & $\pi_{S n-C 2}$ & $\pi_{S n-C 2}^{*}$ & 4.95 & 0.013 \\
\hline SUM & & 48.34 & 0.324 & SUM & & 34.84 & 0.098 \\
\hline
\end{tabular}
calculated with frontier orbital gap. The results show the following trend in HOMO-LUMO gap for the complexes:

Table 9. Results of second-order perturbation theory analysis of the Fock matrix within the NBO basis for the Sn complexes calculated at B3LYP/LANL2DZ. 
$\left[\mathrm{SnMe}_{2} \mathrm{Cl}_{2}\left(\mathrm{H}_{2}\right.\right.$ acacMeen $\left.)\right]>\left[\mathrm{SnMe}_{2} \mathrm{Cl}_{2}\left(\mathrm{H}_{2}\right.\right.$ acacen $\left.)\right]$ and $\left[\mathrm{SnMe}_{2} \mathrm{Cl}_{2}\left(\mathrm{H}_{2}\right.\right.$ acacen $\left.)\right]>\left[\mathrm{SnMe}_{2} \mathrm{Cl}_{2}\left(\mathrm{H}_{2} \mathrm{acCF}_{3} \mathrm{en}\right)\right]>[\mathrm{Sn}-$ $\mathrm{Me}_{2} \mathrm{Cl}_{2}\left(\mathrm{H}_{2}\right.$ acPhen $\left.)\right]$. According to the thermodynamic studies, the formation constants of the complexes depend upon the steric and the electronic characteristic of the ligands.

\section{Acknowledgements}

We are grateful to Islamic Azad University, Darab branch Council for their financial support. The authors express their sincere thanks to Dr. Banafsheh Esmaielzadeh (Department of Anatomy, Bushehr University of Medical Science, Bushehr, I. R. Iran) for providing biological data preparation.

\section{References}

1. M. Alias, H. Kassum, C. Shakir, J. Asso. Arab. Univ. Bah. App. Sci. 2014, 15, 28-34.

2. L. Li, Q. Guo, J. Dong, T. Xu, J. Li, J. Photochem. Photobiol. Biol. 2013, 125, 56-62.

http://dx.doi.org/10.1016/j.jphotobiol.2013.05.007

3. S. Shit, R. Sankolli, T. N. G. Row, Acta Chim. Slov. 2014, 61, 59-66.

4. L. Shivakumar, K. Shivaprasad, H. D. Revanasiddppa, Spectrochim. Acta, Part A, Mol. Biomol. Spect. 2012, 97, 659666. http://dx.doi.org/10.1016/j.saa.2012.07.015

5. K. Singh, Y. Kumar, P. Puri, M. Kumar, C. Sharma, Eur. J. Med. Chem. 2012, 52, 313-321.

http://dx.doi.org/10.1016/j.ejmech.2012.02.053

6. A. A. El-Sherif, T. M. A. Ehdebss, Spectrochim. Acta, Part A. Mol. Biomol. Spect. 2011, 79, 1803-1814.

http://dx.doi.org/10.1016/j.saa.2011.05.062

7. R. Aman, G. Matela, J. Chem. 2013, 11, 1-4. http://dx.doi.org/10.1155/2013/637290

8. S. Mondal, R. Modak, S. Goswami, J. Mol. Struct. 2013, 1037, 352-360.

http://dx.doi.org/10.1016/j.molstruc.2013.01.004

9. I. Sheikhshoaie, S. Saeednia, Arab. J. Sci. Eng. 2010, 35, 5360.

10. P. Pattanayak, J. L. Pratihar, D. Patra, P. Brandoo, D. Mal, V. Felix, Polyhedron 2013, 59, 23-28. http://dx.doi.org/10.1016/j.poly.2013.04.034

11. H. Esfandiari, S. Jameh-bozorgi, S. Esmaielzadeh, M. Mohammadi Shafiee, M. Ghashang, Res. Chem. Intermed. 2013, 39, 3319-3325. http://dx.doi.org/10.1007/s11164-012-0844-y

12. K. H. Yang, Acta Chim. Slov. 2014, 61, 629-636.

13. K. Jamil, R. Wajid, M. Bakhyiar, M. Danish, J. Iran. Chem. Soc. 2010, 7, 495-499.

14. T. Sedaghat, F. Jalilian, J. Iran. Chem. Soc. 2009, 6, 271276.

15. G. Matela, R. Aman, C. Sharma, S. Chaudhary, Indian. J. Adv. Chem. Sci. 2013, 1, 157-163.
16. S. J. Blunden, P. A. Cussack, R. Hill. The industrial use of tin chemicals, Royal society of chemistry, London, 1985.

17. S. Sihag, S. Pareek, M. Gupta, S. Varshney, A. K. Varshney, World. J. Pharma. Pharmaceu. Sci. 2014, 3, 2164-2176.

18. Y. Li, Z. Wang, P. Guo, L. Tang, R. Ge, S. Ban, Q. Chai, L. Niu, Q. Li, J. Inorg. Biochem. 2014, 133, 1-7. http://dx.doi.org/10.1016/j.jinorgbio.2013.12.002

19. H. Pruchnik, T. Lis, M. Latocha, A. Zielinska, S. Ulaszewski, I. Pelinska, F. P. Pruchnik, J. Inorg. Biochem. 2012, 111, 25-32. http://dx.doi.org/10.1016/j.jinorgbio.2012.02.024

20. A. Syed, R. Khajuria, S. Kumar, A. Kaur Jassal, M. S. Hundal, S. K. Pandey, Acta Chim. Slov. 2014, 61, 866-874.

21. N. Mahalakshmin, R. Rajavel, Arab. J. Chem. 2014, 7, 509517. http://dx.doi.org/10.1016/j.arabjc.2010.11.010

22. T. Priya Devi, R. K. Hemakumar Singh, Rasayan. J. Chem. 2010, 3, 266-270.

23. M. Amirnasr, M. Rasouli, K. Mereiter, Inorg. Chim. Acta 2013, 404, 230-235. http://dx.doi.org/10.1016/j.ica.2013.04.007

24. M. Asadi, K. Mohammadi, S. Esmaielzadeh, B. Etemadi, H. K. Fun, Polyhedron 2009, 28, 1409-1418. http://dx.doi.org/10.1016/j.poly.2009.03.018

25. M. Asadi, K. Mohammadi, S. Esmaielzadeh, B. Etemadi, H. K. Fun, Inorg. Chim. Acta 2009, 362, 4913-4920. http://dx.doi.org/10.1016/j.ica.2009.07.025

26. S. Esmaielzadeh, L. Azimian, K. Shekoohi, H. Esfandiari, M. Asadi, Z. Zare, A. Rahmani Nejad, K. Mohammadi, Inorg. Chim. Acta 2013, 405, 155-162. http://dx.doi.org/10.1016/j.ica.2013.05.001

27. M. Asadi, S. Esmaielzadeh, K. Mohammadi, Acta Chim. Slov. 2009, 56, 927-935.

28. B. Bordas, P. Sohar, G. Matolcsy, P. Berencsi, J. Org. Chem. 1972, 37, 1727-1730. http://dx.doi.org/10.1021/jo00976a011

29. K. Nag, D. S. Joardar, Inorg. Chim. Acta 1975, 14, 133-141. http://dx.doi.org/10.1016/S0020-1693(00)85733-3

30. S. Chandra, S. Raizada, M. Tyagi, A. Gautam, Bioinorg. Chem. Appl. 2007, 2007, 51483-51489.

31. M. J. Frisch, G. W. Trucks, H. B. Schlegel, G. E. Scuseria, M. A. Robb, J. R. Cheeseman, J. A. Montgomery, J. T. Vreven, K. N. Kudin, J. C. Burant, J. M. Millam, S. S. Iyengar, J. Tomasi, V. Barone, B. Mennucci, M. Cossi, G. Scalmani, N. Rega, G. A. Petersson, H. Nakatsuji, M. Hada, M. Ehara, K. Toyota, R. Fukuda, J. Hasegawa, M. Ishida, T. Nakajima, Y. Honda, O. Kitao, H. Nakai, M. Klene, X. Li, J. E. Knox, H. P. Hratchian, J. B. Cross, C. Adamo, J. Jaramillo, R. Gomperts, R. E. Stratmann, O. Yazyev, A. J. Austin, R. Cammi, C. Pomelli, J. W. Ochterski, P. Y. Ayala, K. Morokuma, G. A. Voth, P. Salvador, J. J. Dannenberg, V.G. Zakrzewski, S. Dapprich, A. D. Daniels, M. C. Strain, O. Farkas, D. K. Malick, A. D. Rabuck, K. Raghavachari, J. B. Foresman, J. V. Ortiz, Q. Cui, A. G. Baboul, S. Clifford, J. Cioslowski, B. B. Stefanov, G. Liu, A. Liashenko, P. Piskorz, I. Komaromi, R. L. Martin, D. J. Fox, T. Keith, M. A. Al-Laham, C.Y. Peng, A. Nanayakkara, M. Challacombe, P. M. W. Gill, B. Johnson, W. Chen, M. W. Wong, C. Gonzalez, J. A. Pople, Gaus- 
sian 03, Computer program for computational chemistry, Gaussian Inc., Pittsburgh PA, USA, 2003.

32. A. D. Becke. J. Chem. Phys. 1993, 98, 5648-5652. http://dx.doi.org/10.1063/1.464913

33. P. J. Hay, W. R. Wadt, J. Chem. Phys. 1985, 82, 270-283. http://dx.doi.org/10.1063/1.448799

34. A. D. Kullkarni, S. A. Patil, V. H. Naik, P. S. Badami, Med. Chem. Res. 2011, 20, 346-354. http://dx.doi.org/10.1007/s00044-010-9327-0

35. V. Philip, V. Suni, M. R. P. Kurup, M. Nethaji, Polyhedron 2004, 23, 1225-1233. http://dx.doi.org/10.1016/j.poly.2004.02.004

36. V. Govindaraj, S. Ramanathan, Turk. J. Chem. 2014, 38, 521-530. http://dx.doi.org/10.3906/kim-1301-83

37. K. Mohammadi, M. Rastegari, Spectrochim. Acta Part A, Mol. Biomol. Spect. 2012, 97, 711-716. http://dx.doi.org/10.1016/j.saa.2012.07.062

38. G. B. Bagihalli, P. G. Avaji, P. S. Badami, Eur. J. Med. Chem. 2008, 43, 2639-2649. http://dx.doi.org/10.1016/j.ejmech.2008.02.013

39. A. Ray, S. Mitra, A. D. Khalaj, C. Atmani, N. Cosquer, S. Ttiki, J. M. C. C. Juan, S. C. Serra, C. J. G. Garcia, R. J. Buycher, E. Garribba, D. Xu, Inorg. Chim. Acta 2010, 363, 3583-3588.

40. B. Yearwood, Inter. J. Mod. Chem. 2014, 6, 65-73.

41. S. A. Sadeek, M. S. Refa, J. Korean Chem. Soc. 2006, 50, 107-115. http://dx.doi.org/10.5012/jkcs.2006.50.2.107

42. B. Yearwood, S. Parkin, D. A. Atwood. Inorg. Chim. Acta 2002, 333, 124-131. http://dx.doi.org/10.1016/S0020-1693(02)00803-4

43. E. M. Martin, R. D. Bereman, Inorg. Chim. Acta 1991, 188, 221-231. http://dx.doi.org/10.1016/S0020-1693(00)80376-X

44. J. S. Gasas, A. Castineiras, F. Condori, M. D. Couce, U. Russo, A. Sanchez, R. Seoane, J. Sordo, J. M. Vorela, Polyhedron 2003, 22, 53-65.

http://dx.doi.org/10.1016/S0277-5387(02)01331-1
45. A. Ray, D. Sadhukhan, G. M. Rosair, C. J. Gomes-Garcia, S. Mitra, Polyhedron 2009, 28, 3542-3550. http://dx.doi.org/10.1016/j.poly.2009.07.017

46. A. Trujillo, M. Fuentealba, D. Carrillo, C. Manzar, J. Hamon, J. Organomet. Chem. 2009, 694, 1435-1440. http://dx.doi.org/10.1016/j.jorganchem.2008.12.036

47. R. K. Sharma, Y. Singh, A. K. Rai, Phosphorus, Sulfur and Silicon and Relat. El. 2002, 166, 221-230. http://dx.doi.org/10.1080/10426500008076543

48. T. Sedaghat, S. Menati. Inorg. Chem. Commun. 2004, 7, 760-762. http://dx.doi.org/10.1016/j.inoche.2004.04.003

49. M. Pelli, G. G. Lobbia, M. Moncini, R. Spagna, C. Sanlini, J. Organomet. Chem. 2006, 691, 1615-1621. http://dx.doi.org/10.1016/j.jorganchem.2005.12.020

50. D. Dakernieks, H. Zhu, D. Masi, C. Mealli, Inorg. Chem. 1992, 31, 3601-3606. http://dx.doi.org/10.1021/ic00043a021

51. J. Otera, J. Organomet. Chem. 1981, 221, 57-61. http://dx.doi.org/10.1016/S0022-328X(00)81028-1

52. J. Otera, A. Kusaba, T. Hinoishi, Y. Kawasaki, J. Organomet. Chem. 1982, 228, 223-228. http://dx.doi.org/10.1016/S0022-328X(00)84321-1

53. W. Rehman, K. B. Musa, B. Amin, J. Braz. Chem. Soc. 2005, $16,827-834$. http://dx.doi.org/10.1590/S0103-50532005000500023

54. D. L. Leggett, Computational methods for the determination of formation constant, Plenum Press, New York, USA, 1985. http://dx.doi.org/10.1007/978-1-4684-4934-1

55. H. L. H. Mendoza, R. C. H. Rios, J. Mex. Chem. Soc. 2011, 55, 142-147.

56. J. Aihara, J. Phys. Chem. 1999, 103, 7487-7495. http://dx.doi.org/10.1021/jp990092i

57. R. C. Haddon, T. Fukunaga, Tetrahedron Lett. 1988, 29, 4843-4847. http://dx.doi.org/10.1016/S0040-4039(00)80623-1

58. K. Raif, A. Azizoglu; Polyhedron 2007, 26, 5069-5074. http://dx.doi.org/10.1016/j.poly.2007.07.021

\section{Povzetek}

Sintetiziranih je bilo več 1:1 kompleksov $\mathrm{SnMe}_{2} \mathrm{Cl}_{2}$ z nesimetričnimi štiriveznimi Schiffovimi bazami z NNOS koordinacijsko sfero. Spojine so bile okarakterizirane $\mathrm{z}$ različnimi fizikalno-kemijskimi metodami, kot so elementna analiza, molska prevodnost, ${ }^{1} \mathrm{H}$ in ${ }^{119} \mathrm{Sn}$ NMR, IR in masna spektrometrija. IR spektroskopski podatki kažejo, da je peto koordinacijsko mesto na kositrovem atomu zasedeno s kisikovim atomom Schiffove baze. Na podlagi analiznih rezultatov je predlagana geometrija sintetiziranih kompleksov okrog kositrovega atoma trigonalna bipiramidalna. Določena je bila tudi in vitro antibakterijska aktivnost na Staphylococcus aureus in Escherichia Coli. Ugotovljeno je bilo, da so spojine antibakterijsko aktivne. Z DFT/B3LYP metodo so bile izračunane geometrije kompleksov ter analizirane elektronske strukture. Tvorbene konstante kompleksov so bile določene spektrofotometrično pri $25^{\circ} \mathrm{C} v \mathrm{DMF}$. 